\title{
Canine Brucellosis: An Update
}

\author{
Renato L. Santos ${ }^{1 *}$, Tayse D. Souza ${ }^{1}$, Juliana P. S. Mol ${ }^{1}$, Camila Eckstein ${ }^{1}$ and \\ Tatiane A. Paíxão ${ }^{2}$ \\ ${ }^{1}$ Departamento de Clínica e Cirurgia Veterinárias, Escola de Veterinária, Universidade Federal de Minas Gerais, Belo \\ Horizonte, Brazil, ${ }^{2}$ Departamento de Patologia Geral, Instituto de Ciências Biológicas, Universidade Federal de Minas Gerais, \\ Belo Horizonte, Brazil
}

Canine brucellosis is an infectious and zoonotic disease caused by Brucella canis, which has been reported worldwide, and is a major public health concern due to close contact between dogs and humans. In dogs, canine brucellosis manifests with abortion outbreaks, reproductive failure, enlargement of lymph nodes, and occasionally affects the osteoarticular system, although the occurrence of asymptomatic infections in dogs are not uncommon. In humans, the disease is associated with a febrile syndrome, commonly with non-specific symptoms including splenomegaly, fatigue, and weakness. Infection of dogs occurs mostly by the oronasal route when in contact with contaminated tissues such as aborted fetuses, semen, urine, and vaginal secretions. In humans, contact with contaminated fluids from infected dogs is an important source of infection, and it is an occupational risk for veterinarians, breeders, laboratory workers, among other professionals who deal with infected animals or biological samples. The diagnosis in dogs is largely based on serologic methods. However, serologic diagnosis of canine brucellosis remains very challenging due to the low accuracy of available tests. Molecular diagnostic methods have been increasingly used in the past few years. Treatment of infected dogs is associated with a high frequency of relapse, and should be employed only in selected cases. Currently there are no commercially available vaccines for prevention of canine brucellosis. Therefore, development of novel and improved diagnostic methods as well as the development of efficacious and safe vaccination protocols are needed for an effective control of canine brucellosis and its associated zoonotic risk.

Keywords: Brucella canis, brucellosis, dog, abortion, reproductive diseases, zoonosis

\section{INTRODUCTION}

The term "brucellosis" refers to a disease that results from infection of humans and animals with Brucella spp. Although there are much more genetic variations among strains of Escherichia coli or serotypes of Salmonella enterica than among Brucella species (1), Brucella spp. are usually host restricted, which has been the traditional approach for naming the species. For instance, among classical Brucella spp., namely B. melitensis, B. suis, B. abortus, B. canis, B. ovis, and B. neotomae have small ruminants, pigs, cattle, dogs, sheep, and rodents as their preferred hosts, respectively (2). During the past recent years, the genus underwent a marked expansion with the recognition of additional species, including: B. ceti $(3,4)$, B. pinnipedialis (4), B. microti (5), B. inopinata (6), $B$. papionis (7), and B. vulpis (8), which have cetaceans (e.g., whales and dolphins), seals, common vole (Microtus arvalis), undetermined host, baboons, and wolves as preferential hosts, respectively. 
Brucellosis is one of the most important zoonotic diseases worldwide $(9,10)$, and most of Brucella species are capable of infecting humans, although they have a highly variable zoonotic potential. B. melitensis is the most pathogenic species of Brucella for humans, with the exposure to only 1-10 CFU (colony forming units) being sufficient for establishment of infection, whereas $B$. suis and B. abortus have intermediate zoonotic potential. B. canis has the lowest zoonotic potential among the classic Brucella spp., and there are no documented cases of human infection with $B$. ovis $(11,12)$.

The pathobiology of brucellosis in livestock species have been extensively studied $(13,14)$, particularly due to its zoonotic and public health significance (11) as well as due to highly significant economic losses for the animal industry (15). In contrast, studies on canine brucellosis are mostly based on fragmented seroepidemiologic surveys (16). Importantly, canine infections with $B$. canis are widespread, which considering the limitations for accurate diagnosis in dogs and human patients (17), it certainly makes human brucellosis associated with B. canis a markedly neglected zoonotic disease. Therefore, the goal of this review was to provide an updated overview of the literature regarding different aspects $B$. canis infection in dogs as well as its relevance as a zoonotic disease, considering perspectives for improving the control of this disease.

\section{EPIDEMIOLOGY OF CANINE BRUCELLOSIS}

B. canis is the most common cause of canine brucellosis (18, 19), although occasional infections with B. melitensis, $B$. abortus, or B. suis occur in dogs that have close contact with tissues or secretions of infected livestock animals, especially raw milk, aborted fetuses, and placentas (20, 21). Interestingly, B. canis was isolated from a lymph node of a cow, but the clinical and epidemiological implications of this finding is unknown (22).

In dogs, there is no evidence of breed predisposition, and the high number of well-documented outbreaks in beagles may be due to the broad use of this breed for research purposes (23-26). B. canis infection in dogs has been reported during outbreaks in kennels $(23,25-28)$ or serological surveys of stray and pet dogs (29-34). Serologic surveys demonstrated higher frequencies of $B$. canis infections in stray dogs when compared to responsibly owned dogs $(30,31)$, probably due to the absence of mating control in stray dogs, which favors transmission of the disease. In a recent study performed in Mississippi, the prevalence of $B$. canis infection in shelter dogs was $2.3 \%$, but the prevalence in shelters varies from 0 to $8.6 \%$, which indicates that a small number of shelters may have a high seroprevalence of brucellosis (34).

B. canis was first isolated in 1966 from aborted fetuses in a Beagle kennel in the USA during an outbreak of abortions and reproductive failures (35). Since then, canine brucellosis caused by $B$. canis has been diagnosed in several countries $(16,19,24,27$, 36), with the exception of Antarctica (37). Although the literature supports the notion that $B$. canis infection has a worldwide distribution (38), there are no consistent epidemiological studies assessing the prevalence of canine brucellosis. The lack of specific and efficient commercial laboratory tests may contribute to neglect the importance of canine brucellosis in many countries $(17,19,39)$. The frequency of canine brucellosis in different parts of the world is represented in Figure 1. All studies employed for drawing the map (Figure 1) are cited in Supplementary Table 1 (40-125).

Studies using molecular tools, such as variable-number tandem repeat analysis (VNTR) and multiple loci VNTR analysis (MLVA), fatty-acid profiles or cellular fatty acid profiling (CFAP) methyl ester analysis, have been performed to identify markers in $B$. canis isolates to trace the origin and spread of infection in dogs and humans $(27,118,126-129)$, although it may not always be possible.

In addition to being found in dogs, anti- $B$. canis antibodies have also been detected in wild canids $(130,131)$, and domestic and wild felines (131-133), although felines are considered resistant to brucellosis (130). There is serological evidence of antibodies anti-B. canis in other captivity (131) or freeranging $(131,134)$ wild carnivore species, but the epidemiological importance of these species in canine brucellosis is unknown. Experimental infection demonstrated that B. canis is capable of infecting non-human primates (135), although natural infections have not been diagnosed in those animals.

Routes of $B$. canis infection include oral, nasal, conjunctival, and genital mucosa. Venereal transmission is important and occurs when $B$. canis is shed in the semen of infected dogs, particularly during the first 8 weeks after infection, although dogs may continue to shed $B$. canis intermittently in the semen for years $(19,24,136)$. Infection can also be transmitted from an infected bitch to a susceptible male through contact with vaginal discharge during mating. B. canis may also be eliminated in the urine of male and female dogs. Puppies may be infected by intrauterine vertical transmission or after birth by the oronasal route through contaminated milk, contact with placental membranes or vaginal discharge after abortion (19, 137, 138). B. canis infection is associated with high neonatal mortality rates (46). Infected puppies that survive may become important sources of infection as permanent carriers of $B$. canis (26).

Large numbers of infectious bacteria are shed into the environment after abortions or through vaginal or seminal secretions. Therefore, fomites play an important role in the transmission of infection. Infected kennels must adopt stringent disinfection procedures and segregate feeding utensils and other materials to prevent spreading of infection (137). Canine blood transfusions can be a source of infection considering that $B$. canis causes intermittent but persistent bacteremia $(18,24)$. Transmission via blood-sucking fleas and ticks has not been confirmed, although $B$. canis have been isolated from these parasites (139).

Introduction of new dogs into a kennel, either as acquisitions or for breeding purposes without testing for B. canis favors the spreading of the disease (27). Usually, dogs are not properly tested since a successful diagnosis is laborious and challenging because it requires a combination of more than one 


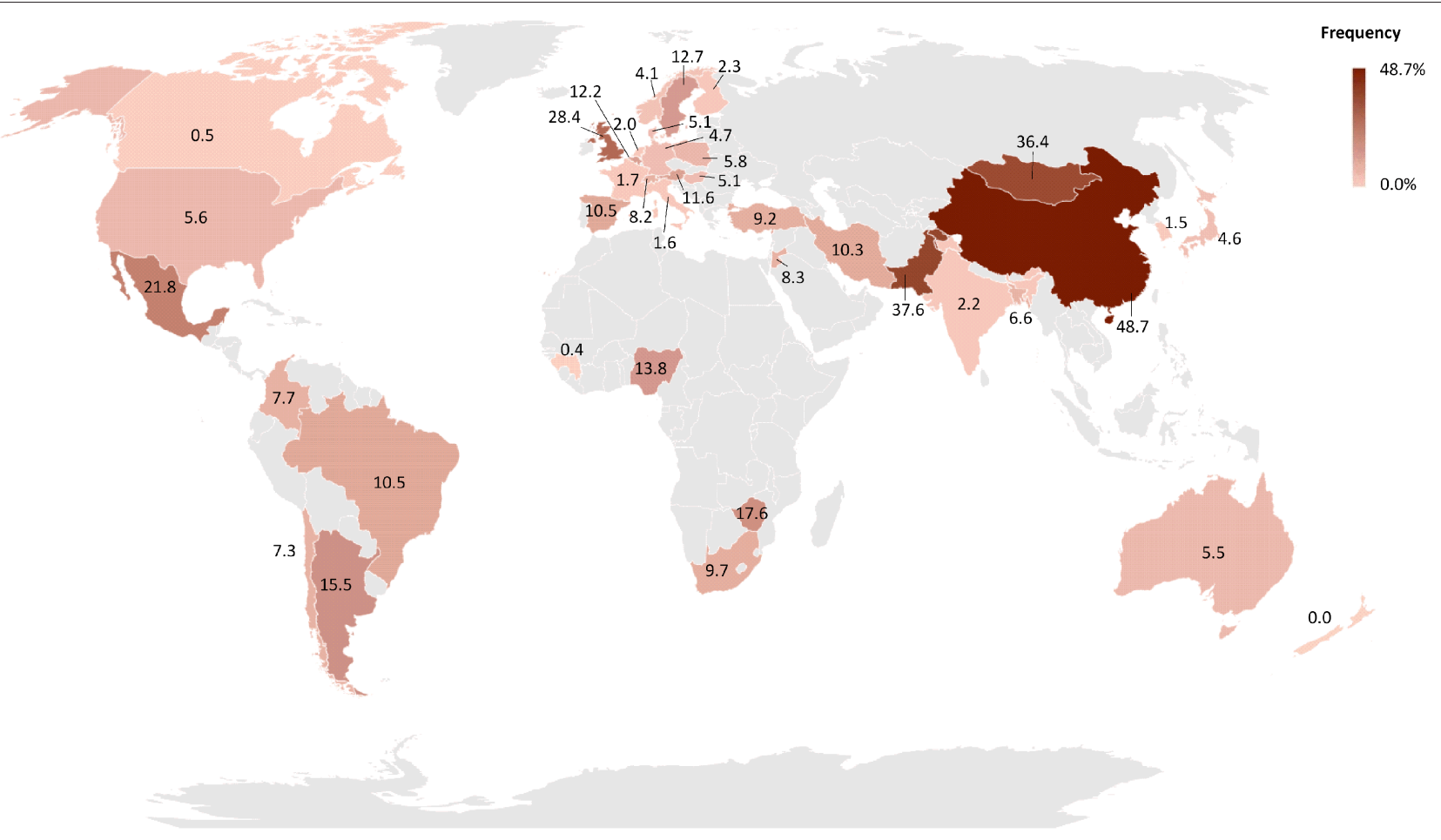

FIGURE 1 | Worldwide distribution of the frequency of $B$. canis infected dogs by country. The frequency of each country was obtained by weighted average of the frequency reported in each study available on PubMed and Google Scholar. The map was generated using Microsoft Excel software. Regions in gray indicate countries without epidemiological surveys while countries showing patterns with black lines indicate countries with reports of dogs infected with $B$. canis but without studies of disease frequency.

laboratorial test and repeated sampling of biological specimens $(17,26,28,140)$.

\section{HUMAN INFECTIONS WITH BRUCELLA CANIS}

A recent study demonstrated that $B$. canis is stealthier than pathogenic smooth Brucella (141), which supports the notion that $B$. canis may be under-diagnosed in human patients. The incidence of human brucellosis is estimated as half a million new cases per year, and this is considered an underestimation. The prevalence is extremely variable among different countries, and it is directly associated with infection in domestic animals and control policies $(36,142)$.

Human infections with B. canis were first reported in 1968, affecting individuals who had contact with infected dogs (23, 143). Although human infections with B. canis have been described in several countries, the prevalence of the disease is unknown $(24,36,140,144-147)$. Human infection with B. canis is considered self-limiting and occasional. It has been estimated that only $1 \%$ of the diagnosed human brucellosis are due to $B$. canis infection $(146,148)$. However, the incidence of human $B$. canis infection is may be underestimated.

Human B. canis infections are acquired through the oronasal route by direct contact with infected dogs, particularly by the contact with contaminated aborted fetuses or secretions. Laboratorial manipulation of the agent without protection is another relevant source of infection. As detailed in Table 1, for most cases of human infections with $B$. canis, there is an identifiable previous contact with infected dogs or contaminated biological materials in the laboratory $(23,31,138,143,144$, 149-152). Lucero et al. (152) described an outbreak of human brucellosis affecting three families who purchase puppies from an infected bitch, demonstrating high risk of transmission from infected dogs to their contacts. Children can also be considered a risk group due to close proximity to pet dogs (144).

Human brucellosis is considered an occupational disease, so veterinarians, pet store workers, kennels employees and owners, dog caregivers, dog trainers, and laboratory technicians are professionals with the higher risk of occupational exposure to infection $(23,140,144,152,153)$. A study of 306 asymptomatic adults with occupational exposure risk demonstrated a seroprevalence of $3.6 \%$ for B. canis (140). An interesting epidemiological study made by Monroe et al. (144) demonstrated higher prevalence of anti- $B$. canis antibodies in veterinarians and patients with unknown origin fever. Human B. canis infection may result from contact with aerosols formed during routine laboratory practices or accidental laboratorial exposure $(23,138,151,154)$. Importantly, manipulation of most Brucella spp., including B. canis, should be performed under biosafety level 3 conditions (155). 
TABLE 1 | Profile of human patients infected with Brucella canis.

\begin{tabular}{lll}
\hline Category & Frequency (\%) & \\
\hline Sex & Woman & $35.7(10 / 28)$ \\
& Man & $64.3(18 / 28)$ \\
History of disease & & $21.4(6 / 28)$ \\
Infection source & Laboratorial & $10.7(3 / 28)$ \\
& contact with infected/suspected dog & $78.5(22 / 28)$ \\
Age (years) & Below to 10 & $14.3(4 / 28)$ \\
& $>11$ e $<20$ & $17.8(5 / 28)$ \\
& $>21$ e $<50$ & $46.4(13 / 28)$ \\
& Above to 50 & $17.8(5 / 28)$ \\
& Non-described & $3.6(1 / 28)$ \\
\hline
\end{tabular}

Human brucellosis caused by $B$. canis resembles the clinical manifestations associated with other Brucella spp. infections (Figure 2), with unspecific symptoms, including intermittent fever, chills, sweating, loss of appetite, weight loss, fatigue, headaches, back pain or joint pain $(146,148,156)$. Although $B$. canis is considered less pathogenic to human than other Brucella species, severe manifestations such as endocarditis, aneurysm, peritonitis, arthritis, osteomielitis, and epidural abscess have been described in B. canis infected patients (138, 149, 157-160). Neurobrucellosis, another important clinical manifestation of the disease in human patients, is usually due to $B$. melitensis infection, but there are reports of rare cases of neurologic disease associated with $B$. canis infection (161). Secondary neurological syndromes such as Guillain-Barré (138) have been associated with B. canis infection as well as with other Brucella spp. (162). Association of $B$. canis infection with other metabolic or immune diseases can aggravate brucellosis in human patients $(138,163-$ 165). Indeed, immunodeficiency may be a risk factor for human infection with B. canis $(163,164)$.

Due to limitations of clinical or laboratorial diagnosis, human brucellosis due to $B$. canis is underdiagnosed, and its importance in public health is largely neglected $(140,166)$.

\section{PATHOGENESIS}

Molecular mechanisms of pathogenesis are highly conserved among different species of Brucella spp. Therefore, unless stated otherwise, the mechanisms described here are common to the genus - not $B$. canis-specific. The goal of this section is not to provide a thorough literature review on Brucella spp. pathogenesis, which has already been reviewed $(12,167,168)$, but to give an overview of Brucella pathogenesis with emphasis on the few studies that have focused specifically on B. canis.

The most common routes of Brucella infection are through the digestive or respiratory mucosa. Thus, a key step in Brucella pathogenesis is its ability to cross intact intestinal epithelia, particularly through $\mathrm{M}$ cells, in a completely stealthy fashion without activating innate immune response from the host (169). The two-component regulatory system BvrR/BvrS is required for
Brucella spp. invasion and surveillance in phagocytic and nonphagocytic cells, specifically by recruiting GTPases, particularly Cdc42 (170). Lipopolysaccharide (LPS) is also considered an important virulence factor of Brucella spp. (171). Interestingly, naturally rough Brucella strains (due to the lack of Opolysaccharide chain of its LPS molecules) such as B. canis tend to invade host cells more efficiently than smooth strains, but they have lower survivability within host cells in culture or in vivo (172-174). Smooth LPS is protective against several host bactericidal mechanisms, including antimicrobial peptides, nitric oxide, and free radicals (171). Therefore, outer membrane proteins (Omp) also play a role in virulence $(175,176)$.

Earlier studies identified the virB operon-encoded Brucella type IV secretion system (T4SS) that is essential for intracellular survival and persistence in vivo (177, 178). This system translocates bacterial effector proteins directly into the host cell cytosol. In the absence of a functional T4SS, Brucella is not capable of directing the intracellular trafficking of the Brucellacontaining vacuole toward the rough endoplasmic reticulum (RER), which constitutes the intracellular replicative niche for Brucella (179).

As mentioned above, most of the studies on Brucella pathogenesis do not involve $B$. canis, but a few particularities have been described. For instance, B. canis infection induces a poor pro-inflammatory response even in its preferential host, whereas this species is much less prone to induce inflammation than some of the smooth pathogenic Brucella species under experimental conditions, resulting in much lower induction of IFN $\gamma$ production and inflammatory lesions (141).

\section{PATHOLOGY}

In general, Brucella spp. infection in livestock results in reproductive disease, which is usually associated with abortion and placentitis in pregnant females, and epididymitis or orchitis in males $(13,14)$. In contrast, human brucellosis manifests as a febrile disease with a broader range of symptoms $(11,180)$. Here we will focus on gross and microscopic lesions that have been associated with $B$. canis infection in dogs.

$B$. canis has been originally identified as a cause of abortion in dogs. In bitches, the infection is usually associated with metritis, placentitis, and abortion, with focal necrosis of the chorionic villi and numerous bacteria within trophoblastic cells (Figure 3) (35). Aborted fetuses may have bronchopneumonia, myocarditis, renal hemorrhage, lymphadenitis, and hepatitis (35). These B. canisinduced lesions in the canine pregnant uterus and fetuses are similar to lesions induced by Brucella spp. in other animal species $(13,14)$, although $B$. canis has been detected in a wide range of tissues from naturally infected neonates, including stomach, intestines, kidney, central nervous system, umbilicus, liver, lungs, lymph nodes, and spleen (46). In addition to abortion, $B$. canis infection is associated with the birth of weak puppies with a high neonatal mortality rate $(35,46)$. B. canis-infected male dogs develop epididymitis, orchitis, and prostatitis, which result in poor sperm quality and infertility (181). Epididymitis seems to be a more common primary lesion than orchitis (35), 


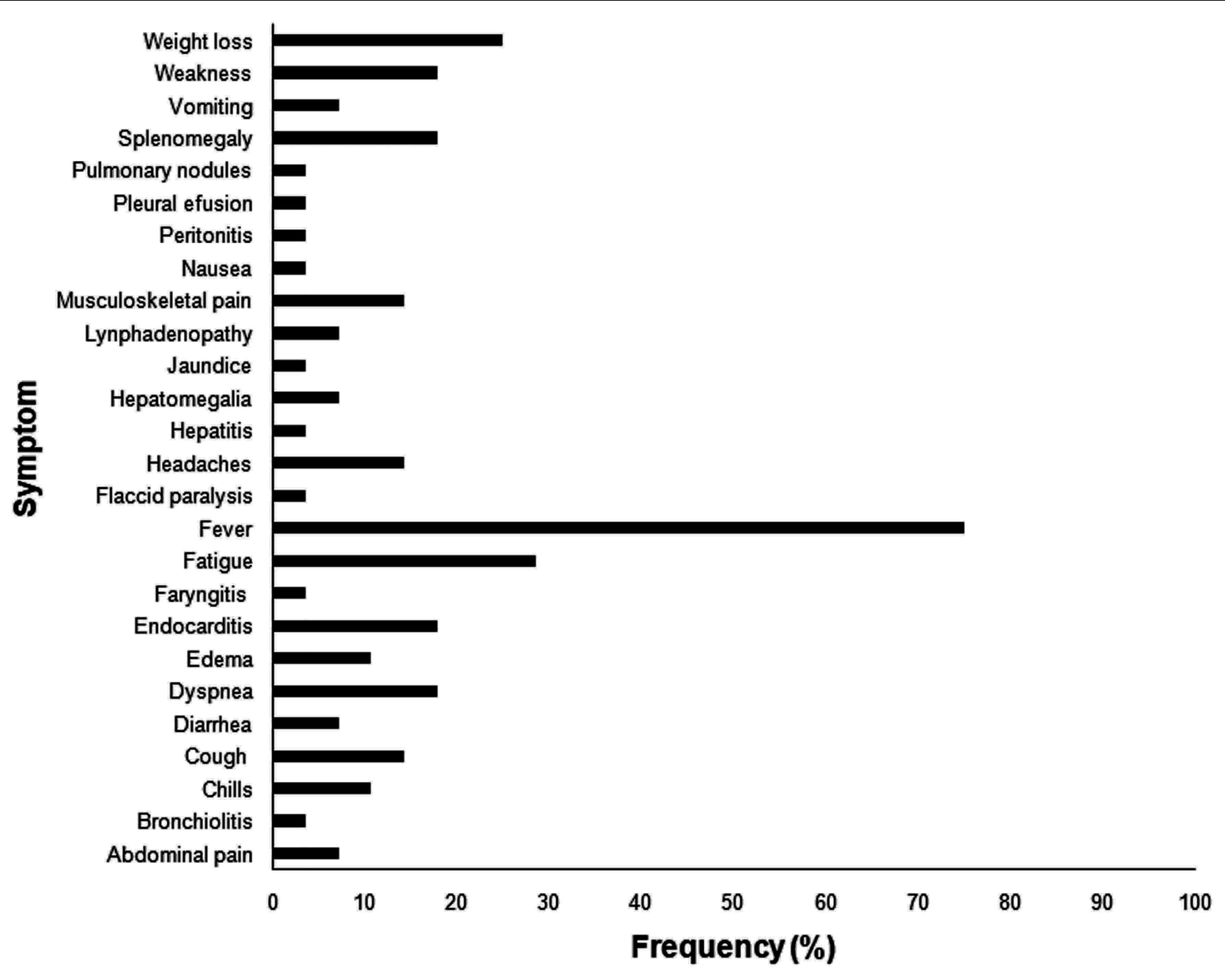

FIGURE 2 | Frequency of symptoms reported in human brucellosis caused by Brucella canis. *All references used in the figure are listed in Supplementary Table $\mathbf{1 .}$

which contrasts with cattle that often develop orchitis due to $B$. abortus infection, but it is similar to B. ovis infection in rams, which causes primarily epididymitis (14). In addition to epididymitis, B. canis infection in male dogs is also often associated with inflammatory changes in the prostate gland and renal pelvis (182).

Less common manifestations of canine brucellosis include ocular and skeletal lesions, which are characterized by mildto-moderate anterior uveitis, iris hyperpigmentation, vitreal inflammatory infiltrate, and multifocal chorioretinitis (183) and diskospondylitis $(184,185)$, respectively.

\section{CLINICAL MANIFESTATION}

Most $B$. canis infected dogs do not develop any clinical signs other than enlarged lymph nodes. Some of them may present loss of vigor and reproductive failure, and most of the abortions commonly between 45 and 55 days of gestation $(35,186)$, although in some cases they occur in the initial phase of gestation (between 10 and 35 days), when it is easily confused as failure in conception $(19,35)$.
Reproductive failure and interrupted whelping pattern have also been reported in association with B. canis infection (187). There may be repeated and consecutive abortions or alternated abortions and normal whelping, which affects infected females that are otherwise healthy. However, bitches are occasionally reported to be depressed for several weeks (35). Vaginal discharges are common after abortion, with variable duration (from 1 to 6 weeks), amount and appearance of the exudate, which is usually serosanguineous, but may be viscous and grayish green $(16,35)$.

Stillbirth or birth of weak puppies and neonatal death are also often associated with $B$. canis infection, but infected and apparently healthy puppies may be present in the same litter $(26,35,46,187)$. In some cases, enlarged lymph nodes are still observed in infected 2-month-old puppies (35), and bacteremia persists until at least 5 months of age (26). Surviving puppies that carry the bacteria represent a potential source of infection for people in close contact with them $(129,152)$ and might have a role in maintenance of the bacteria in the canine population (26).

Although bacteremia may be persistent for several months, fever is not a typical clinical feature in dogs naturally or experimentally infected. Infection with $B$. canis usually remains 


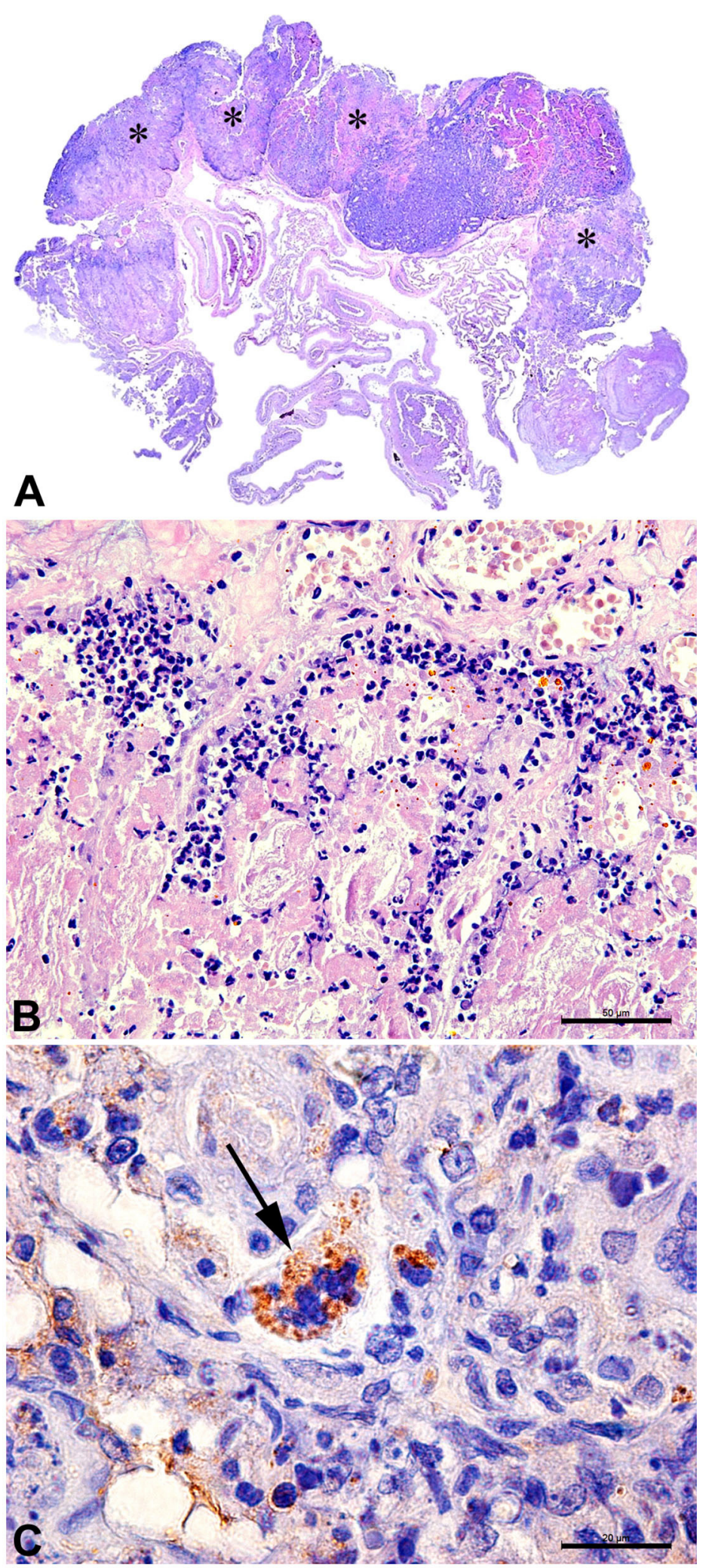

FIGURE 3 | Canine placenta. (A) Sub-macroscopic view of the placenta with multiple focally extensive areas of necrosis (*) characterizing a necrotizing placentitis. (B) Necrotic tissue and marked neutrophilic inflammatory infiltrate. HE Bar $=50 \mu \mathrm{m}$. (C) Immunohistochemistry for detection of Brucella sp.: trophoblast with intracytoplasmatic immunolabed coccobacilli (arrow). Bar $=20 \mu \mathrm{m}$. 
unnoticed when the dog does not have reproductive activity $(35,137,182)$. Frequent findings in canine brucellosis during physical examination include long term enlargement of lymph nodes, especially the submandibular and retropharyngeal. The epididymis may be enlarged and firm, with scrotal dermatitis, and testicular atrophy. Orchitis has also been reported in $B$. canis infection, and although testicular swelling is infrequent and usually not detectable, pain on gentle palpation of testicles or epididymis may be noticed, and distention of tunica vaginalis cavity with fibrinopurulent exudate has been reported (35, 137, 182). Small testicular abscesses and prostate enlargement due to prostatitis with pelvic compression can be visualized by ultrasonography (137).

Loss of libido and male infertility has also been reported in B. canis-infected dogs (35). Semen from infected dogs may have sperm defects and head-to-head agglutination. Chronically infected dogs may be oligospermic or azoospermic (188). Auto antibodies against sperm contribute to infertility in infected dogs (189). However, the clinical manifestation may vary with less frequent clinical signs, especially in castrated dogs.

Congenitally infected puppies that survive or dogs infected later in life may present arthritis, ocular disease, discospondylitis, urinary retention (137), and osteomyelitis (190). Discospondylitis is the most common orthopedic disorder attributed to B. canis infection in dogs. In these cases, back pain, lameness, and neurologic deficits may be present. Radiography will show typical lesions and differential diagnosis with other infectious agents will require serology and/or isolation of Brucella from blood or lesions to address the appropriate treatment (184, 191-193).

Ocular lesions associated with B. canis infection have been reported and successfully treated in adult dogs. Ocular lesions were the exclusive complaint in three otherwise healthy dogs that presented recurrent blepharospasm and uveitis with hyperpigmentation of iridal surface, myosis, synechiae, lens capsule opacification and pigmentation, retinal lesions, vitreous opacity and optic disk hyperemia (183).

It has been reported by breeders that competing dogs presented loss of field-trial performance and poor coat quality after infection with B. canis (35).

\section{LABORATORIAL DIAGNOSIS}

This section discusses the most important diagnostic methods for canine brucellosis. A thorough review on diagnosis of human brucellosis has been recently published (194). As pointed out, a precise clinical diagnosis of canine brucellosis is not achievable. Therefore, laboratorial tests are essential for a definitive diagnosis. As in cases of other Brucella spp. infections, the gold standard for diagnosis of $B$. canis infection is isolation of the agent $(19,130)$ associated with biochemical tests $(195-197)$ or more recently matrix-assisted laser desorption/ionization timeof-flight mass spectrometry (MALDI-TOF-MS) (198). B. canis, as well as other Brucella spp., grows well-under aerobic conditions on conventional media, such as dextrose or tryptic soy agar. However, considering its zoonotic potential, this procedure poses a considerable risk for laboratory personnel, requirinig biosafety level 3 conditions (151, 154, 199, 200).

In the absence of samples from aborted fetuses or vaginal secretions, whole blood is the sample of choice for B. canis isolation. In contrast to other Brucella spp., B. canis infection is associated with bacteremia that persists for 2-4 weeks, reaching up to $10^{4} \mathrm{CFU} / \mathrm{mL}$ of blood $(19,24,130)$. Isolation of $B$. canis from blood samples may be done by direct or indirect culture methods (195). The use of liquid or biphasic media is recommended since B. canis may be found in very low numbers in blood samples (196). Importantly, regardless of the employed method, isolation of B. canis has low sensitivity, often resulting in false negative results. Some factors may further decrease the intrinsically low sensitivity of isolation, including: (i) antimicrobial treatment; (ii) use of EDTA, which inhibits bacterial growth (heparin or sodium citrate should be used as anticoagulant instead); and (iii) inadequate conditions for storage and transportation of samples $(196,201)$. Therefore, additional diagnostic methods are always recommended $(195,196)$.

In addition to blood, other samples are very useful for $B$. canis isolation. Vaginal and uterine secretions should be sampled during the proestrus and/or estrus, when there is an increased risk of bacteremia, or from bitches that have aborted (202). Samples of fetal membranes, aborted and stillbirth fetuses must be cultured when available, since these samples usually contain high bacterial loads. Semen samples should also be subjected to culture, particularly between 3 and 11 weeks after infection, when higher bacterial amounts are shed in the semen. After this period, shedding of $B$. canis in the semen becomes intermittent with low concentrations, and, therefore, cultures are often negative $(18,203)$. Urine samples are also useful for isolation, mostly between 8 and 30 weeks post infection. Concentrations of B. canis in the urine range from 10 to $10^{2}$ $\mathrm{CFU} / \mathrm{mL}$, and cystocentesis is the method of choice to prevent contamination $(130,202)$, although urine collected through the urethra may contain semen, which is an additional source of $B$. canis (202). In cases of B. canis-induced uveitis, aqueous humor is a suitable sample for culture, whereas in cases of discospondylitis or osteomyelitis, bone marrow aspirates are the samples of choice $(65,202,204)$. At necropsy, several tissue samples should be sampled for culture, including lymph nodes, spleen, liver, and genital organs.

Direct diagnosis can also be achieved by detecting $B$. canis genomic DNA in biological samples by polymerase chain reaction (PCR) (205-208). This technique is faster than culture and it is not affected by bacterial viability or sample contamination $(205,209)$. Whole blood is the sample of choice for PCR, and although serum may also be used, it results in lower sensitivity (210). DNA extraction from blood samples must be performed with appropriate protocols to remove PCR inhibitors (208, 211-213). Importantly, the absence of bacteremia, antimicrobial drug usage, and PCR inhibitors (heparin) in blood samples, may also influence the result. Semen and tissue samples may also be employed for PCR (202).

PCR routinely used for diagnosis of canine brucellosis are genus-specific, targeting gene sequences that are conserved among Brucella spp. such as bcsp31 (214) 16S ribosomal subunit 
$(215,216)$, and recA (217). PCR targeting these genes can be performed with DNA extracted from isolates or clinical samples. A species-specific PCR diagnosis can be achieved by multiplex PCR that requires purified bacterial DNA, and therefore are not applicable to clinical samples, requiring DNA extracted from isolates. Other techniques include the Bruce-Ladder PCR (218220), the Suis-Ladder PCR (219), the HOOF-Prints PCR (221, 222), and the MLVA16 PCR (223-225). Real time quantitative PCR based on single nucleotide polymorphism (SNP) and high resolution melt (HRM) analysis on bcsp31 and 16S RNA ribosomal gene, allow identification of the genus Brucella, and in some cases the species, but this technique is currently restricted to the diagnosis of human brucellosis and for evaluation of treatment efficacy (226-232). Furthermore, these are expensive and labor intensive techniques.

Serologic tests are useful for diagnostic purposes since infected dogs remain serologically positive for several months even in the absence of bacteremia. Importantly, B. canis is serologically distinguished from $B$. melitensis, B. abortus, and $B$. suis, which carry a smooth LPS, and therefore their antigens do not react with anti-B. canis antibodies (195). However, none of the serological tests currently used for the diagnosis of canine brucellosis are completely satisfactory. Serologic diagnosis of $B$. canis infection is challenging, and a combination of different tests is highly recommended ideally in association with bacterial isolation $(17,202,233)$. The serologic tests that are more frequently used for the diagnosis of $B$. canis infection include: rapid slide agglutination test (RSAT) (234), rapid slide agglutination test with 2-mercaptoethanol (2MERSAT) (235), and agar gel immunodiffusion test (AGID) (236). These tests detect antibodies against surface antigens of Brucella spp., particularly antibodies against rough LPS. Although these tests may have appropriate levels of sensitivity, false-positive results are common due to cross-reaction with other bacteria such as Pseudomonas, Bordetella bronchiseptica, Streptococcus, Staphylococcus, Salmonella, Yersinia enterocolitica, and Escherichia coli (19, 130, 231, 233, 237-239).

RSAT and 2ME-RSAT are serologic tests commonly used for screening of $B$. canis infection. The use of non-mucoid $B$. canis strains for antigen preparation may also decrease falsepositive results $(195,202,240)$. The tube agglutination test (TAT) is considered a semi-quantitative test and it is employed as a confirmatory test for RSAT or 2ME-RSAT (189, 202, 203), although false-positive or false-negative results are not uncommon (201, 233).

AGID, which is based on surface proteins as antigens, is capable of detecting precipitins between 5 and 10 weeks after infection. However, this method has important drawbacks including cross reactions and subjectivity for interpreting lines of precipitins (241). In addition to superficial antigens, cytoplasmic antigens may also be used for AGID, resulting in a highly specific test for Brucella spp. since cytoplasmic antigens are conserved only in organisms belonging to the genus Brucella. In this case, cytoplasmic antigens obtained by sonication of $B$. canis allow detection of antibodies in chronically infected dogs, even at 3 years post-infection in the absence of bacteremia. However, in acute infections, cytoplasmic antigen-based AGID tends to detect precipitins at later stages of infection when compared to surface antigen-based AGID (201, 203, 204).

Several enzyme-linked immunosorbent assay (ELISA) protocols have been applied to the diagnosis of $B$. canis infection, but sensitivity and specificity varies according to the antigen used (204, 238, 241-244). Antigens employed in ELISA protocols include: B. canis surface antigens (245), cytoplasmic antigens (242), antigens extracted by heated saline solution (HSS) from non-mucoid B. canis (M-variant), etc (238). Indirect ELISA is considered more specific, but less sensitive than TAT for screening (203). However, this method is more sensitive than agglutination methods and AGID (19, 204, 246). Furthermore, ELISAs can detect antibodies in chronically infected dogs that that test negative by 2ME-RSAT and AGID (247). ELISA can detect antibodies at 30 days post infection, and it may be useful as a confirmatory test $(93,98,241)$.

The complement fixation test (CFT) is considered a confirmatory test for B. ovis and B. abortus infection (248-251). Although it has high specificity and sensitivity, CFT has not been routinely used for diagnosis of canine brucellosis (252). Immunochromatographic assays have been developed for the diagnosis of $B$. canis infections $(247,253,254)$. These are simple and rapid assays, but they have low sensitivity when compared to other traditional screening methods (247).

Regardless of the serologic method employed, false-negative results are commonly observed during the first 3 to 4 weeks after infection, even when bacteremia is present. Therefore, dogs should be tested at least twice in 30 days intervals. Considering different serologic methods, dogs remain positive for 8-12 weeks after infection (202). Serum samples should be preferably obtained from bitches at proestrus, estrus or during gestation or immediately after abortion (202). Serum samples must be free of hemolysis since hemoglobin may result in agglutination and, consequently, false-positive results (235).

\section{TREATMENT}

\section{Treatment in Humans}

The treatment of brucellosis in humans is based on the use of antibiotics capable to act in intracellular medium for an adequate length of time (156), including doxycycline (138, 153, $157,159,163-165,255)$, streptomycin $(143,150,153,154,256$, $257)$, rifampicin $(129,138,157,159,163,255)$, gentamicin (138, $160,165)$, trimethropim-sulfametoxazole $(129,138,150,152)$, ofloxacin (157), ciprofloxacin (164), tetracycline (23, 255, 258), ampicillin (138, 143, 160, 259), sulfadiazine (154), ceftriaxone (152) and cephalothin $(138,160)$.

In the first reports of human infection with $B$. canis, Morisset and Spink (23) and Munford et al. (259) described the use of monotherapy with tetracycline and ampicillin, respectively. However, the association of two or more antibiotics is considered the most consistent and effective treatment due to the high relapse rates of monotherapy (260). The treatment is usually prolonged and varies (up to 6 weeks) according to antibiotics (156).

The treatment for children with doxycycline and tetracycline is not recommended due to the irreversible staining of the 
teeth $(9,260)$ and inhibition of bone growth (9). Cotrimoxazole and rifampicin are not indicated for use in young children, and the use of these drugs separately in monotreatment commonly results in treatment failure (9). In this case, the treatment is usually based on the association of trimethoprimsulfamethoxazole with rifampicin for 4-6 weeks, with no negative effects on the efficacy of treatment (129).

In pregnant woman, tetracyclines are contraindicated due to permanent staining of fetal dentition and the potential to induce necrosis of the liver and pancreatitis (9). Sulfamethoxazole and trimethoprim individually or combined (cotrimoxazole) should be avoided during gestation. These drugs are potentially neurotoxic for the fetus due to the elevation of plasma bilirubin that reaches the central nervous system causing kernicterus (256). In some cases of complication due to Brucella spp. infection as osteoarticular impairment and endocarditis, the treatment needs to be prolonged, and relapses in these cases are common $(9,157,257)$.

\section{Treatment in Dogs}

In dogs, the treatment with antibiotics is not encouraged, especially due to the high rates of relapse, and the cure for the disease still uncertain after antibiotic treatment, resulting in high risk of transmission to humans and other dogs $(16,261)$. In addition, expensive antibiotic may be prohibitive for some owners (262). It is important to highlight that antibiotic therapy does not completely eliminate B. canis. Therefore, absence of the clinical signs after treatment does not indicate the absence of the bacterium (263).

$B$. canis isolated from dogs are usually susceptible to doxycycline and tetracycline $(264,265)$, whereas some $B$. canis strains are considered more resistant to streptomycin and tetracycline than other Brucella spp. (264). Importantly, enrofloxacin and streptomycin have synergic activity in vitro against the bacteria, while doxycycline and rifampicin have antagonistic effects (265).

Treatment with oxytetracycline for 4 weeks and streptomycin in the 1st week of treatment results in effective treatment in $79 \%$ of dogs, when elimination of bacteremia and absence of B. canis in lymph nodes, spleen and reproductive organs are considered (262). Enrofloxacin have good results to prevent occurrence of abortion, with results that are similar to streptomycin, which may be toxic and is not indicated during pregnancy (263).

\section{CONTROL AND PREVENTION}

B. canis infection causes infertility in dogs $(24,137)$ and has progressively gained more attention from dog breeders due to significant economic losses as well as the public health risk $(24,38)$.

Unfortunately, there is not any commercially available vaccine for prevention of canine brucellosis. Therefore, control measures include (i) screening tests for dogs and kennels suspected of having brucellosis, (ii) treatment or euthanasia of infected dogs, and (iii) elimination of the bacteria from the environment $(24,137)$.
In commercial kennels, dogs should be subjected to screening tests annually or twice a year, and in case of positive or inconclusive results, dogs must be subjected to quarantine and confirmatory tests $(24,202)$. In case of confirmation of the diagnosis, euthanasia should be considered (24).

Precaution is required when introducing new dogs into a kennel. Newly acquired dogs must remain isolated for at least 1 month, and they should only be introduced in the kennel after two negative diagnostic test results with an interval of one month $(24,202,204,245,266-268)$. Dogs with clinical signs compatible with brucellosis should not be acquired (202). Besides, dogs from a positive kennel should be monthly tested for at least 3 months after becoming negative, particularly prior to breeding $(24,137,202)$. Importantly, since canine brucellosis is a zoonosis with high occupational risk, owners and/or kennel employees must be properly educated and protected, mostly in order to prevent contact with infected dogs and secretions, especially during parturition or abortion. Personnel must be aware of $B$. canis infection in the kennel and be subjected to diagnostic tests or treatment if needed $(137,202)$.

Elimination of $B$. canis from the environment is another very important control procedure. B. canis does not survive for prolonged periods under environmental conditions. It is quickly killed by most disinfectants including $1 \%$ sodium hypochlorite, $70 \%$ ethanol, ethanol/iodine solutions, glutaraldehyde, and formaldehyde $(24,137)$. However, organic matter and low temperatures may impair disinfectant efficiency. Surfaces may be decontaminated with $2.5 \%$ sodium hypochlorite, which should be maintained over the surface for at least $1 \mathrm{~h}$. Decontamination of body surfaces may be done with $70 \%$ ethanol or iodine solutions. Equipment may be decontaminated by autoclaving at $121^{\circ} \mathrm{C}$ for at least $15 \mathrm{~min}$ or by dry heat at $160-170^{\circ} \mathrm{C}$ for at least $1 \mathrm{~h}$. Boiling for $10 \mathrm{~min}$ also inactivates Brucella (269).

In case of pet dogs infected with Brucella, owners must be informed about the zoonotic risks before choosing treatment or euthanasia. Orchiectomy or ovary-hysterectomy should be considered to eliminate the primary site of infection and decrease the risk of transmission. In addition, infected dogs must be treated since the pathogen remains in tissues of castrated dogs in spite of a lower risk of transmission (24, 202). Electing treatment instead of euthanasia should be performed only under rigorous supervision of a veterinarian, and in case of treatment is chosen, infants should not be in contact with the infected dog (270). Dog owners must also be aware that even under stringent conditions, treatment may not result in cure, and a second round of treatment may be required $(24,202)$. Treated dogs must be tested again, and negative results by serology, PCR and bacterial isolation may be interpreted as a presumptive of cure (202). In addition, measures for controlling environmental contamination should be applied to households $(24,137)$.

Good practices for controlling zoonotic diseases in general play an important role in controlling canine brucellosis. Therefore, contraceptive methods, preferably surgical sterilization, for stray dog populations are important in this context.

In spite of a significant research effort in the field of Brucella vaccinology (271), studies specifically aiming the development 
of a vaccine for canine brucellosis are scarce and restricted to the last decade $(272,273)$. Strategies employed for experimental vaccines include inactivated vaccines (273), a recombinant outer membrane proteins (Omp31) $(274,275)$, recombinant VirB proteins (276), attenuated mutant vaccine strains such as a $B$. canis mutant in SST4 (272) and a mutant versions of $B$. abortus RB51 vaccine strain (277). However, despite its attenuation, the vaccine strain B. abortus RB51 retains pathogenic potential (277). Live attenuated vaccines provide the highest levels of protection (271). Indeed, recently two new vaccine candidates for canine brucellosis have emerged, namely a mutant strain $B$. canis $\Delta v j b R$ (278) and $B$. ovis $\triangle a b c B A$ (279). This later vaccine strain has been developed by our group taking advantage of the antigenic similarities between $B$. canis and $B$ ovis, utilizing a background that has no zoonotic potential since there is not a reported case of human brucellosis attributed to $B$. ovis, and no residual pathogenicity for animals including sheep (280). A recent study demonstrated that the vaccine candidate $B$. ovis $\triangle a b c B A$ protects against experimental challenge with $B$. canis in mice, and when this vaccine strain is encapsulated in alginate and administered to dogs, it is not shed in the semen or urine and is safe (279).

\section{FUTURE PERSPECTIVES}

Diagnosis of $B$. canis infection is very challenging. Although the dog is the most common host of $B$. canis, canine infections with other Brucella spp. such as B. suis (281) and B. abortus (282) may occur. Therefore, the development of effective and accurate $B$. canis-specific diagnostic methods is extremely relevant.

Currently, prevention and control of canine brucellosis are not easily achieved, especially due to the difficulty in identifying infected dogs, which could prevent spreading of the disease.

\section{REFERENCES}

1. Tsolis RM. Comparative genome analysis of the alpha-proteobacteria: relationships between plant and animal pathogens and host specificity. Proc Natl Acad Sci USA. (2002) 99:12503-5. doi: 10.1073/pnas.212508599

2. Xavier MN, Costa EA, Paixão TA, Santos RL. The genus Brucella and clinical manifestations of brucellosis. Ciênc Rural. (2009) 39:2252-60. doi: 10.1590/S0103-84782009005000167

3. Ewalt DR, Payeur JB, Martin BM, Cummins DR, Miller WG. Characteristics of a Brucella species from a bottlenose dolphin (Tursiops truncatus). J Vet Diagn Invest. (1994) 6:448-52. doi: 10.1177/104063879400600408

4. Foster G, Osterman BS, Godfroid J, Jacques I, Cloeckaert A. Brucella ceti sp. nov. and Brucella pinnipedialis sp. nov. for Brucella strains with cetaceans and seals as their preferred hosts. Int J Syst Evol Microbiol. (2007) 57:2688-93. doi: 10.1099/ijs.0.65269-0

5. Scholz HC, Hubalek Z, Sedlácek I, Vergnaud G, Tomaso H, Al Dahouk S, et al. Brucella microti sp. nov., isolated from the common vole Microtus arvalis. Int J Syst Evol Microbiol. (2008) 58:375-82. doi: 10.1099/ijs.0.65356-0

6. Scholz HC, Nöckler K, Göllner C, Bahn P, Vergnaud G, Tomaso H, et al. Brucella inopinata sp. nov., isolated from a breast implant infection. Int $J$ Syst Evol Microbiol. (2010) 60:801-8. doi: 10.1099/ijs.0.011148-0

7. Whatmore AM, Davison N, Cloeckaert A, Al Dahouk S, Zygmunt MS, Brew $\mathrm{SD}$, et al. Brucella papionis sp. nov., isolated from baboons (Papio spp.). Int J Syst Evol Microbiol. (2014) 64:4120-8. doi: 10.1099/ijs.0.065482-0

8. Scholz HC, Revilla-Fernández S, Al Dahouk S, Hammerl JA, Zygmunt MS, Cloeckaert A, et al. Brucella vulpes sp. nov., isolated from mandibular lymph
In this context, development of novel diagnostic methods is highly desirable as well as the development of efficacious and safe vaccines.

In addition to the development of novel diagnostic methods and vaccines for the control of canine brucellosis, which will be a turning point in controlling this disease, raising awareness among human health professionals could have a significant impact. This may lead to a better knowledge of the impact of human brucellosis associated with $B$. canis, allowing proper therapeutic interventions and mitigation of deleterious effects of the disease.

\section{AUTHOR CONTRIBUTIONS}

RS and TP contributed revising the manuscript and acting as senior authors. All authors contributed to conceptualize, write the manuscript, contributed writting the body of the manuscript, and approved the manuscript for publication.

\section{FUNDING}

Work in RLS lab was supported by CNPq (Conselho Nacional de Desenvolvimento Científico e Tecnológico, Brazil), FAPEMIG (Fundação de Amparo a Pesquisa do Estado de Minas Gerais, Brazil), and CAPES (Coordenação de Aperfeiçoamento de Pessoal de Nível Superior, Brazil).

\section{SUPPLEMENTARY MATERIAL}

The Supplementary Material for this article can be found online at: https://www.frontiersin.org/articles/10.3389/fvets. 2021.594291/full\#supplementary-material nodes of red foxes (Vulpes vulpes). Int J Syst Evol Microbiol. (2016) 66:2090-8. doi: 10.1099/ijsem.0.000998

9. Corbel MJ. Brucellosis in Humans and Animals. Switzerland: WHO Press, World Health Organization (2006).

10. Pappas G. The changing Brucella ecology: novel reservoirs, new threats. Int J Antimicrob Agents. (2010) 36:S8-11. doi: 10.1016/j.ijantimicag.2010. 06.013

11. Young EJ. Human brucellosis. Rev Infect Dis. (1983) 5:821-42.

12. Xavier MN, Paixão TA, Hartigh ABD, Tsolis, RM, Santos RL. Pathogenesis of Brucella spp. Open Vet Sci J. (2010) 4:109-18. doi: 10.2174/1874318801004010109

13. Carvalho Neta AV, Mol JP, Xavier MN, Paixão TA, Lage AP, Santos RL. Pathogenesis of bovine brucellosis. Vet J. (2010) 184:146-55. doi: 10.1016/j.tvjl.2009.04.010

14. Poester FP, Samartino LE, Santos, RL. Pathogenesis and pathobiology of brucellosis in livestock. Rev Sci Tech. (2013) 32:105-15. doi: 10.20506/rst.32.1.2193

15. Santos RL, Martins TM, Borges AM, Paixão TA. Economic losses due to bovine brucellosis in Brazil. Pesqui Vet Bras. (2013) 33:759-64. doi: 10.1590/S0100-736X2013000600012

16. Holst BS, Löfqvist K, Ernholm L, Eld K, Cedersmyg M, Hallgren G. The first case of Brucella canis in Sweden: background, case report and recommendations from a northern European perspective. Acta Vet Scan. (2012) 54:18. doi: 10.1186/1751-0147-54-18

17. Mol JP, Guedes ACB, Eckstein C, Quintal APN, Souza TD, Mathias LA, et al. Diagnosis of canine brucellosis: comparative study of 
different serological tests and PCR. J Vet Diagn Invest. (2020) 32:77-86. doi: $10.1177 / 1040638719891083$

18. Carmichael LE. Brucella canis. In: Nielsen K, Duncan JR, editors. Animal Brucellosis. Boca Raton, FL: CRC Press (1990). p. 335-50.

19. Wanke MM. Canine brucellosis. Anim Reprod Sci. (2004) 82:195-207. doi: 10.1016/j.anireprosci.2004.05.005

20. Woldemeskel M. Zoonosis due to Bruella suis with special reference to infection in dogs (Carnivores): a brief review. Open J Vet Med. (2013) 3:213-21. doi: 10.4236/ojvm.2013.33034

21. Baek BK, Lim CW, Rahman MS, Kim CH, Oluoch, A, Kakoma I. Brucella abortus infection in indigenous Korean dogs. Can J Vet Res. (2003) 67:312-4.

22. Baek BK, Park MY, Islam MA, Khatun MM, Lee SI, Boyle SM. The first detection of Brucella canis in cattle in the Republic of Korea. Zoonoses Public Health. (2012) 59:77-82. doi: 10.1111/j.1863-2378.2011.01429.x

23. Morisset R, Spink WW. Epidemic canine brucellosis due to a new species, Brucella canis. Lancet. (1969) 2:1000-2.

24. Hollett RB. Canine brucellosis: outbreaks and compliance. Theriogenology. (2006) 66:575-87. doi: 10.1016/j.theriogenology.2006.04.011

25. Brennan SJ, Ngeleka M, Philibert HM, Forbes LB, Allen AL. Canine brucellosis in a Saskatchewan kennel. Can Vet J. (2008) 49:703-8.

26. Gyuranecz M, Szeredi L, Rónai Z, Dénes B, Dencso L, Dán Á, et al. Detection of Brucella canis-induced reproductive diseases in a kennel. J Vet Diagn Invest. (2011) 23:143-7. doi: 10.1177/104063871102300127

27. Brower A, Okwumabua O, Massengill C, Muenks Q, Vanderloo P, Duster $\mathrm{M}$, et al. Investigation of the spread of Brucella canis via the U.S. interstate dog trade. Int J Infect Dis. (2007) 11:454-8. doi: 10.1016/j.ijid.2006. 12.009

28. Hofer E, Bago ZN, Revilla-Fernndez S, Melzer F, Tomaso HL, Lopez-Goñi II, et al. First detection of Brucella canis infections in a breeding kennel in Austria. New Microbiol. (2012) 35:507-10.

29. Flores-Castro R, Segura R. A serological and bacteriological survey of canine brucellosis in Mexico. Cornell Vet. (1976) 66:347-52.

30. Lovejoy GS, Carver HD, Moseley IK, Hicks M. Serosurvey of dogs for Brucella canis infection in Memphis, Tennessee. Am J Public Health. (1976) 66:175-176.

31. Brown J, Blue JL, Wooley RE, Dreesen DW. Brucella canis infectivity rates in stray and pet dog populations. Am J Public Health. (1976) 66:889-91.

32. Dreer MKP, Gonçalves DD, Caetano ICS, Gerônimo E, Menegas PH, Bergo $\mathrm{D}$, et al. Toxoplasmosis, leptospirosis and brucellosis in stray dogs housed at the shelter in Umuarama municipality, Paraná, Brazil. J Venom Anim Toxins Incl Trop Dis. (2013) 19:23. doi: 10.1186/1678-9199-19-23

33. Yoak AJ, Reece JF, Gehrt SD, Hamilton IM. Disease control through fertility control: secondary benefits of animal birth control in Indian street dogs. Prev Vet Med. (2014) 113:152-6. doi: 10.1016/j.prevetmed.2013. 09.005

34. Hubbard K, Wang M, Smith DR. Seroprevalence of brucellosis in Mississippi shelter dogs. Prev Vet Med. (2018) 159:82-6. doi: 10.1016/j.prevetmed.2018.09.002

35. Carmichael LE, Kenney RM. Canine abortion caused by Brucella canis. J Am Vet Med Assoc. (1968) 152:605-16.

36. Lucero NE, Ayala SM, Escobar GI, Jacob NR. Brucella isolated in humans and animals in Latin America from 1968 to 2006. Epidemiol Infect. (2008) 136:496-503. doi: 10.1017/S0950268807008795

37. Gardner E, Reichel MP. No evidence of Brucella canis infections in New Zealand dogs. Surveillance. (1997) 24:17-8.

38. Hensel ME, Negron M, Arenas-Gamboa AM. Brucellosis in dogs and Public Health risk. Emerg Infect Dis. (2018) 24:1401-6. doi: 10.3201/eid2408.171171

39. Lucero NE, Escobar GI, Ayala SM, Jacob N. Diagnosis of human brucellosis caused by Brucella canis. J Med Microbiol. (2005) 54:457-61. doi: 10.1099/jmm.0.45927-0

40. López G, Ayala SM, Efron AM, Gomez CF, Lucero NE. A serological and bacteriological survey of dogs to detect Brucella infection in Lomas de Zamora, Buenos Aires province. Rev Argent Microbiol. (2009) 41:97-101.

41. Myers DM, Varela-Díaz VM. Serological and bacteriological detection of Brucella canis infection of stray dogs in Moreno, Argentina. Cornell Vet. (1980) 70:258-65.

42. Boeri E, Escobar GI, Ayala SM, Sosa-Estani S, Lucero NE. Canine brucellosis in dogs in the city of Buenos Aires. Medicina (B Aires). (2008) 68:291-7.
43. Medveczky NE, Crichton R. The application of a serological test to screen dogs entering Australia for antibody to Brucella canis. Aust Vet J. (1986) 63:375-7.

44. Buhmann G, Paul F, Herbst W, Melzer F, Wolf G, Hartmann K, et al. Canine brucellosis: Insights Into the epidemiologic situation in Europe. Front Vet Sci. (2019) 6:151. doi: 10.3389/fvets.2019.00151

45. Talukder BC, Samad MA, Rahman AKMA. Comparative evaluation of commercial serodiagnostic tests for the seroprevalence study of brucellosis in stray dogs in Bangladesh. Bangladesh J Vet Med. (2011) 9:79-83. doi: 10.3329/bjvm.v9i1.11217

46. Souza TD, Carvalho TF, Mol JPS, Lopes JVM, Silva MF, Paixão TA, et al. Tissue distribution and cell tropism of Brucella canis in naturally infected canine foetuses and neonates. Sci Rep. (2018) 8:7203. doi: 10.1038/s41598-018-25651-x

47. Almeida AC, Santorelli A, Bruzadelli RMZ, Oliveira MMNF. Soroepidemiologia da brucelose canina causada por Brucella canis e Brucella abortus na cidade de Alfenas, MG. Arq Bras Med Vet Zootec. (2004) 56:275-6.

48. Godoy AM, Peres JN, Barg L. Isolamento de Brucella canis em Minas Gerais, Brasil. Arq Bras Med Vet Zootec da UFMG. (1977) 29:35-42.

49. Souza LA, Viana RCA, Michalick MSM, Reis JKP, Lage AP. Prevalência de infecção por Brucella canis em Belo Horizonte-MG. Rev Bras Med Vet. (2002) 24:127-31.

50. Castro JR, Silva CB, Souza MA, Salaberry SRS, Guimarães EC, Mundim AV. Alterações hematológicas em cães naturalmente infectados por Leptospira spp., Brucella abortus e Brucella canis. Rev Bras Ciênc Vet. (2014) 36:49-54.

51. Moraes CCG, Megid J, Souza LC. Prevalência da brucelose canina na microrregião da Serra de Botucatu, São Paulo, Brasil. Arq Inst Biol. (2002) 69:7-10.

52. Mascolli R, Soto FRM, Bernardi F, Ito FH, Pinheiro SR, Guilloux AGA, et al. Prevalência e fatores de risco para a leptospirose e brucelose na população canina da Estância Turística de Ibiúna, São Paulo, Brasil. Arq Inst Biol. (2016) 83:1-7. doi: 10.1590/1808-1657000842014

53. Reis CB, Hoffmann RC, Santos RS, Turri RJG, Oriani MRG. Research of antibodies anti-Brucella canis and anti-Brucella abortus in wanderring dogs in São João da Boa Vista, State of São Paulo, Brazil (2002-2003). Braz J Vet Res An Sci. (2008) 45:32-4. doi: 10.11606/issn.1678-4456.bjvras.2008.26717

54. Sandoval LA, Ribeiro LOC, Amaral LBS, Feitosa MH, Bazan JM. Incidência da brucelose canina na cidade de São Paulo. O Biológico. (1976) 42:126-32.

55. Larsson MHMA, Larsson CE, Mirandola RMS, Yassuda PH, Grutolla G. Canine brucellosis in São Paulo: serologic survey of kennel and stray dogs. Int J Zoonoses. (1981) 8:85-90.

56. Cortes VA, Oliveira MCG, Ito FH, Vasconcellos SA. Reações sorológicas para Brucella canis em cães errantes capturados na proximidade dos parques públicos, reservas florestais e em áreas periféricas do município de São Paulo - Brasil. Rev Fac Med Vet. (1988) 25:101-7.

57. Keid LB, Soares RM, Morais ZM, Richtzenhain LJ, Vasconcellos SA. Brucella spp. isolation from dogs from commercial breeding kennels in São Paulo State, Brazil. Braz J Microbiol. (2004) 35:161-6. doi: 10.1590/S1517-83822004000100027

58. Keid LB, Chiebao DP, Batinga MCA, Faita T, Diniz JA, de Oliveira TMFS, et al. Brucella canis infection in dogs from commercial breeding kennels in Brazil. Transbound Emerg Dis. (2017) 64:691-7. doi: 10.1111/tbed.12632

59. Azevedo SS, Vasconcellos AS, Alves CJ, Keid LB, Grasso LMPS, Mascolli R, et al. Inquérito sorológico e fatores de risco para a brucelose por Brucella canis em cães do município de Santana de Parnaíba, Estado de São Paulo. Pesqui Vet Bras. (2003) 23:156-60.

60. Porto WJN, Pinheiro Junior JW, Mota RA. Associação entre distúrbios reprodutivos e anticorpos anti-Brucella sp. em cães atendidos em clínicas particulares da cidade de Maceió-AL. Rev Bras Ci Vet. (2008) 15:6-9.

61. Cavalcanti LA, Dasso MG, Oliveira FCS, Viegas SARDA, Almeida MDGÁR, Anunciação AVM, et al. Pesquisa de anticorpos anti-Brucella canis em cães provenientes da região metropolitana de Salvador. Rev Bras Saúde Prod Anim. (2006) 7:176-80.

62. Oliveira MZD. Validação de um Teste ELISA Indireto Para Sorodiagnóstico de Brucelose Canina e sua Aplicação em um Estudo de Soroprevalência em cães da Região Metropolitana de Salvador. [Dissertation/master's thesis]. Salvador, BA: Universidade Federal da Bahia (2008). 
63. Melo SMB, Nascimento RM, Aguiar PHP, Freire SMF. Avaliação sorológica em gel de agarose para diagnóstico de Brucella canis em cães no distrito de Monte Gordo-Camaçari-Bahia. Arqs Esc Med Vet Univ Fed Bahia. (1997) 19:119-27.

64. Vasconcelos RTJ, Alves CJ, Clementino IJ, Araújo Neto JO, Alves FDAL, Batista CDSA, et al. Soroprevalência e fatores de risco associados à infecção por Brucella canis em cães da cidade de Campina Grande, estado da Paraíba. Rev Bras Saúde Prod Anim. (2008) 9:436-42.

65. Fernandes ARF, Azevedo SS, Piatti RM, Pinheiro ES, Genovez MÉ, Azevedo ASD, et al. Brucella canis infection in dogs attended in veterinary clinics from Patos, Paraíba state, Brazil. Braz J Microbiol. (2011) 42:1405-8. doi: 10.1590/S1517-83822011000400023

66. Lima ACT, Souza AB, Souza FAL, Quessada AM, Silva GA, Mineiro ALBB. Frequência de anticorpos anti - Brucella canis em cães de Teresina - PI. Acta Vet Bras. (2014) 8:130-1.

67. Fernandes ARDF, Fernandes AG, Rotondano TEDF, Alves CJ, Kim PDCP, Mota RA, et al. Inquérito sorológico e molecular da brucelose canina no município de Natal, Estado do Rio Grande do Norte. Ciênc Rural. (2013) 43:1629-35. doi: 10.1590/S0103-84782013000900015

68. Lima DC. Estudo Preliminar da Ocorrência de Anticorpos Anti Brucella canis e Brucella abortus em cães de Sergipe. [Dissertation/master's thesis]. Mossoró, RN: Universidade Federal Rural do Semi-Árido (2009).

69. Paz GS, Rocha KS, Lima MS, Jorge EM, Pantoja JCF, Moraes CCG, et al. Seroprevalence for brucellosis and leptospirosis in dogs from Belém and Castanhal, State of Pará, Brazil. Acta Amaz. (2015) 45:265-70. doi: 10.1590/1809-4392201403486

70. Aguiar DM, Cavalcante GC, Vasconcellos SA, Megid, J, Salgado VR, Cruz TF, et al. Ocorrência de anticorpos anti-Brucella abortus e anti-Brucella canis em cães rurais e urbanos do Município de Monte Negro, Rondônia, Brasil. Ciênc Rural. (2005) 35:1216-9. doi: 10.1590/S0103-84782005000500039

71. Dorneles SEM, Santos H, Minharro S, Nascimento-Rocha JM, Mathias LA, Dasso MG, et al. Anticorpos anti-Brucella canis e anti-Brucella abortus em cães de Araguaína, Tocantins. Braz J Vet Res Anim Sci. (2011) 48:167-71. doi: 10.11606/S1413-95962011000200010

72. Santana JÁ, Dorneles EMS, Jayme VS, Galvão SR, Minharro S, Santos H, et al. Risk factors and presence of antibodies to Brucella canis and smooth Brucella in dogs from the municipality of Araguaína, Tocantins, Brazil. Semina: Ciênc Agrár. (2013) 34:2951-6. doi: 10.5433/1679-0359.2013v34n6p2951

73. Silva CPA, Almeida ABPF, Godoy I, Araújo ACP, Aguiar DM, Sousa VRF, et al. Detecção molecular de Brucella canis em cães do Município de Cuiabá, Estado de Mato Grosso. Cien Rural. (2012) 42:1051-6. doi: 10.1590/S0103-84782012005000032

74. Petry AC, Castro BG, Freitas F. Pesquisa de anticorpos anti-Brucella abortus e anti-Brucella canis em cães domiciliados em propriedades leiteiras na região médio-norte de Mato Grosso. Sci Elec Arch. (2019) 12:114-7.

75. Silva LC, Leuzzi Junior LÁ, Nassar JLB, Headley AS, Okano W, et al. Serological detection of Brucella canis in shelter dogs from Northern Parana. Semina: Ciênc Agrár. (2012) 33:2391-5. doi: 10.5433/1679-0359.2012v33n6p2391

76. Machado MA. Porcentagem de cães soropositivos para Brucella canis apresentando problemas reprodutivos atendidos no hospital veterinário da universidade estadual de Londrina. Ars Veterinária. (2013) 29:161-8.

77. Wald VB, Fernandes SJC. Sorologia da brucelose canina no Município de Porto Alegre, RS. Arq Fac Vet UFRS. (1976) 4:92-5.

78. Bosu WT, Prescott JFA. serological survey of dogs for Brucella canis in southwestern Ontario. Can Vet J. (1980) 21:198-200.

79. Higgins R, Hoquet F, Bourque R, Gosselin Y. A serological survey for Brucella canis in dogs in the province of Quebec. Can Vet J. (1979) 20:315.

80. Abarca K, López JC, Peña A, López JC. Tenencia y estado de salud de mascotas de niños inmunocomprometidos, con énfasis en enfermedades zoonóticas. Rev Chil Infectol. (2011) 28:205-10. doi: 10.4067/S0716-10182011000300001

81. Tuemmers C, Luders C, Rojas C, Serri M, Castillo C, Espinoza R. Detection of Brucella canis by immunochromatography method in vague dogs captured in Temuco city, Chile, 2011. Rev Chilena Infectol. (2013) 30:395-401. doi: 10.4067/S0716-10182013000400007
82. Zamora J, Alonso O, Martin R. Brucelosis canina en Valdivia, Chile Estudio serológico y bacteriológico en perros de ciudad. Zentralbl Veterinarmed B. (1980) 27:149-53. doi: 10.1111/j.1439-0450.1980.tb01649.x

83. Peña A, Abarca K, Weitzel T, Gallegos J, Cerda J, García P, et al. One health in practice: a pilot project for integrated care of zoonotic infections in immunocompromised children and their pets in chile. Zoonoses Public Health. (2016) 63:403-9. doi: 10.1111/zph.12241

84. Jiang H, Mao LL, Zhao HY, Li LY, Piao DR, Tian GZ, et al. Reemergence and genetic comparison of Brucella canis in China, using a multiplelocus variable-number tandem-repeat assay. Vet Microbiol. (2012) 3:419-21. doi: 10.1016/j.vetmic.2011.07.014

85. Sánchez-Jiménez MM, Zuluaga JJC, Garcia-Montoya GM, Dabral N, Alzate JF, Vemulapalli R, et al. Diagnosis of human and canine Brucella canis infection: development and evaluation of indirect enzyme-linked immunosorbent assays using recombinant Brucella proteins. Heliyon. (2020) 6:e04393. doi: 10.1016/j.heliyon.2020.e04393

86. Castrillón-Salazar L, Giraldo-Echeverri CA, Sánchez-Jiménez MM, OliveiraAngel M. Factores asociados con la seropositividad a Brucella canis en criaderos caninos de dos regiones de Antioquia, Colombia. Cad Saúde Pública. (2013) 29:1975-87. doi: 10.1590/0102-311x00133013

87. Agudelo-Flórez P, Castro B, Rojo-Ospina R, Henao-Villegas S. Canine brucellosiss: seroprevalence and risk factorsin pets from eleven neighbourhoods in Medellin, Colombia. Revista Salud Pública. (2012) 14:644-56.

88. Pardo A, Pérez C, Góngora A, Luz-Gómez L, Moreno A. Encuesta exploratoria de infección por Brucella canis en perros de VillavicencioColombia. Rev Mvz Cordoba. (2009) 14:1690-6. doi: 10.21897/rmvz.352

89. Dahlbom M, Johnsson M, Myllys V, Taponen T, Andersson M. Seroprevalence of canine herpesvirus-1 and Brucella canis in finnish breeding kennels with and without reproductive problems. Reprod Domest Anim. (2009) 44:128-31. doi: 10.1111/j.1439-0531.2007.01008.x

90. Weber A, Schliesser T. The occurrence of antibodies to Brucella canis in domestic dogs in the Federal Republic of Germany. Berl Munch Tierarztl Wochenschr. (1978) 91:28-30.

91. Von Kruedener RB. Outbreak of a Brucella canis infection in a beagle colony in West Germany. Dev Biol Stand. (1976) 31:251-3.

92. Wintermantel A. Seroepidemiological Investigations of Brucella canis Infection in Dogs and Human Beings in Southern Germany. [Thesis]. Munchen: Ludwig-Maximilians Universitat (1980).

93. Barkha S, Kumar SD, Kumar SD. Immunochemical characterization of antigens of Brucella canis and their use in seroprevalence study of canine brucellosis. Asian Pac J Trop Med. (2011) 4:857-61. doi: 10.1016/S1995-7645(11)60208-3

94. Lingam GS, Kumar AV, Singh S, Kumar MS, Krishnaiah N. Sero occurence of brucellosis in dogs of Telangana state. J Pharm Innov. (2020) 9:452-5.

95. Mosallanejad B, Najafabadi GM, Avizeh R, Mohammadian N. A serological survey on Brucella canis in companion dogs in Ahvaz. Iranian J Vet Res. (2009) 10:383-6. doi: 10.22099/IJVR.2009.1731

96. Behzadi MA, Mogheiseh A. Outbreak investigation of brucellosis at a kennel in Iran. Pakistan Vet J. (2011) 31:379-80.

97. Akhtardanesh B, Ghanbarpour R, Babaei H, Nazer M. Serological evidences of canine brucellosis as a new emerging disease in Iran. Asian Pac J Trop Dis. (2011) 1:177-80. doi: 10.1016/S2222-1808(11)60023-6

98. Ebani VV Cerri D, Fratini F, Bey RF, Andreani E. Serological diagnosis of brucellosis caused by Brucella canis. New Microbiol. (2003) 26:65-73.

99. Nabeshima K, Sato S, Kakeya H, Maruyama S. Seroepidemiological survey of Brucella canis infection in dogs in Japan. Jpn J Vet Res. (2020) 68:129-32. doi: 10.14943/jjvr.68.2.129

100. Saegusa J, Ueda K, Goto Y, Fujiwara K. A survey of Brucella canis infection in dogs from Tokyo area. Nihon juigaku zasshi. (1978) 40:75-80. doi: 10.1292/jvms1939.40.75

101. Takayoshi TAH, Isayama Y. Detection of Brucella canis infection in dogs in Hokkaido. Microbiol Immunol. (1977) 21:295-8.

102. Katami M, Sato H, Yoshimura Y, Suzuki T, Suzuki Y, Nakano K, et al. An epidemiological survey of Brucella canis infection of dogs in the Towada area of Aomori prefecture. J Vet Med Sci. (1991) 53:1113-5. 
103. Kikuchi YK, Sakuma YS, Sato T, Suzuki S, Hoshi S, Sato K, et al. A Survey of Brucella canis infection in dogs sheltered in Tohoku university school of medicine. Jikken Dobutsu. (1979) 28:279-86.

104. Kimura M, Imaoka K, Suzuki M, Kamiyama T, Yamada A. Evaluation of a microplate agglutination test (MAT) for serological diagnosis of canine brucellosis. J Vet Med Sci. (2008) 70:707-9. doi: 10.1292/jvms.70.707

105. Alshehabat M, Obaidat M, Hayajneh W. Seroprevalence of Brucella canis in dogs and at-risk humans in Jordan. Vet Med. (2019) 64:260-5. doi: 10.17221/67/2018-VETMED

106. Lara-Lara J, Argáez-Rodríguez F, Rodríguez-Buenfil J, Alzina-López A. Brucelosis canina. Estudio serológico en perros de la ciudad de Mérida, Yucatán. Rev Bioméd. (1993) 4:15-8.

107. Gonzáles HB, Ramírez RMP, Castro RF, Güemes FS. Reproductive problems in male dogs infected with Brucella canis. Vet Méx. (2004) 35:121-8.

108. Zolzaya B, Selenge T, Narangarav T, Gantsetseg D, Erdenechimeg D, Zinsstag J, et al. Representative seroprevalences of human and livestock brucellosis in two Mongolian provinces. EcoHealth. (2014) 11:356-71. doi: 10.1007/s10393-014-0962-7

109. Patten BE. Antibodies to B. canis in dogs in Papua New Guinea. Aust Vet J. (1987) 64:355.

110. Adesiyun AA, Abdullahi SU, Adeyanju JB. Prevalence of Brucella abortus and Brucella canis antibodies in dogs in Nigeria. J Small Anim Pract. (1986) 27:31-7.

111. Cadmus SIB, Adesokan HK, Ajala OO, Odetokun WO, Perrett LL, Stack JA. Seroprevalence of Brucella abortus and B. canis in household dogs in southwestern Nigeria: a preliminary report. J S Afr Vet Assoc. (2011) 82:56-7. doi: 10.4102/jsava.v82i1.35

112. Anyaoha CO, Majesty-Alukagberie LO, Ugochukwu ICI, Nwanta JA, Anene BM, Oboegbulam SI. Seroprevalencia y factores de riesgo de la brucelosis en perros de los Estados Enugu y Anambra, Nigeria. Rev Med Vet. (2020) 1:45-59. doi: 10.19052/mv.vol1.iss40.5

113. Jamil T, Melzer F, Khan I, Iqbar M, Saqib M, Hussain MH, et al. Serological and molecular investigation of Brucella species in dogs in Pakistan. Pathogens. (2019) 8:294. doi: 10.3390/pathogens8040294

114. Etsebeth C. A Serological Survey to Determinate the Prevalence of Brucella canis Infection in Dogs Within the Nelson Mandela Bay Metropoitan in the Eastern Cape, South Africa. [Thesis]. Roodepoort: University of South AfricaFlorida Campus (2017).

115. Hong JY, Park JS, Han TH, Hwang HS. Investigation of Brucella canis infection in public animal shelters and kennels in Incheon. Korean J Vet Serv. (2010) 33:23-7.

116. Jung JY, Yoon SS, Lee SH, Park JW, Lee JJ, Her M, et al. Prevalence state of canine brucellosis in South Korea during 2015 and 2016. Korean J Vet Res. (2018) 58:125-9.

117. Mateu-de-Antonio EM, Martin M, Casal J. Comparison of serologic tests used in canine brucellosis diagnosis. J Vet Diagn Invest. (1994) 6:257-9.

118. Kaden R, Agren J, Baverud V, Hallgren G, Ferrari S, Borjesson J, et al. Brucellosis outbreak in a Swedish kennel in 2013: determination of genetic markers for source tracing. Vet Microbiol. (2014) 174:523-30. doi: 10.1016/j.vetmic.2014.10.015

119. Egloff S, Schneeberger M, Brawand SG, Krudewig C, Schmitt S, Reichler IM, et al. Brucella canis infection in a young dog with epididymitis and orchitis. Schweiz Arch Tierheilkd. (2018) 160:743-8. doi: 10.17236/sat00190

120. Aras Z, Uçan US. Detection of Brucella canis from inguinal lymph nodes of naturally infected dogs by PCR. Theriogenology. (2010) 74:658-62. doi: 10.1016/j.theriogenology.2010.03.023

121. Onçel T, Akan M, Sareyyüpoglu B, Tel Y, Çiftci A. Seroprevalence of Brucella canis infection of dogs in two provinces in Turkey. Turk J Vet Anim Sci. (2005) 29:779-83.

122. Taylor DJ. Serological evidence for the presence of Brucella canis infection in dogs in Britain. Vet Rec. (1980) 106:102-4.

123. Boebel FW, Ehrenford FA, Brown GM, Angus RD, Thoen CO. Agglutinins to Brucella canis in stray dogs from certain counties in Illinois and Wisconsin. J Am Vet Med Assoc. (1979) 175:276-7.

124. Hoff GL, Nichols JB. Canine brucellosis in Florida: serologic survey of pound dogs, animal shelter workers and veterinarians. Am J Epidemiol. (1974) 100:35-9.
125. Chinyoka S, Dhliwayo S, Marabini L, Dutlow K, Matope G, Pfukenyi DM. Serological survey of Brucella canis in dogs in urban Harare and selected rural communities in Zimbabwe. J S Afr Vet Assoc. (2014) 85:1-5.

126. Brower A, Lucero N, Okwumabua O, Groussaud P, Gopaul KK, Whatmore AM, et al. Newly identified variability in Brucella canis fatty-acid content is associated with geographical origin. Epidemiol Infect. (2013) 141:852-8. doi: $10.1017 /$ S0950268812001240

127. Gyuranecz M, Rannals BD, Allen CA, Jánosi S, Keim PS, Foster JT. Withinhost evolution of Brucella canis during a canine brucellosis outbreak in a kennel. BMC Vet Res. (2013) 9:76. doi: 10.1186/1746-6148-9-76

128. Di D, Cui B, Wang H, Zhao H, Piao D, Tian L, et al. Genetic polymorphism characteristics of Brucella canis isolated in China. PLoS ONE. (2014) 9:e84862. doi: 10.1371/journal.pone.0084862

129. Dentinger CM, Jacob K, Lee LV, Mendez HA, Chotikanatis K, McDonough $\mathrm{PL}$, et al. Human Brucella canis infection and subsequent laboratory exposures associated with a puppy, New York City, 2012. Zoonoses Public Health. (2015) 62:407-14. doi: 10.1111/zph.12163

130. Carmichael LE, Greene CE. Canine brucellosis. In: Greene CE, editor. Infectious Diseases of the Dog and Cat. Philadelphia, PA: W. B. Saunders Company (1990). p. 573-84.

131. Oliveira-Filho EF, Pinheiro JW, Souza MM, Santana VL, Silva JC, Mota RA, et al. Serologic survey of brucellosis in captive neotropical wild carnivores in northeast Brazil. J Zoo Wildl Med. (2012) 43:384-7. doi: 10.1638/20090260.1

132. Larsson MH, Larsson CE, Fernandes WR, da Costa EO, Hagiwara MK. Brucella canis. Inquéritos sorológico e bacteriológico em população felina. Rev Saúde Publ. (1984) 18:47-50. doi: 10.1590/S0034-89101984000100005

133. Almeida ABPF, Silva CPA, Pitchenin LC, Dahroug MAA, Silva GCP, Sousa VRF, et al. Brucella abortus and Brucella canis in captive wild felids in Brazil. Int Zoo Yb. (2013) 47:204-7. doi: 10.1111/j.1748-1090.2012.00188.x

134. Randhawa, AS, Kelly VP, Baker Jr EF. Agglutinins to Coxiella burnetii and Brucella spp, with particular reference to Brucella canis, in wild animals of southern Texas. J Am Vet Med Assoc. (1977) 171:939-42.

135. Percy DH, Egwu N, Jonas AM. Experimental Brucella canis infection in the monkey (Macaca arctoides). Can J Comp Med. (1972) 36:221-5.

136. Shin SJ, Carmichael LE. Canine brucellosis caused by Brucella canis. In: Carmichael LE, editor. Recent Advances in Canine Infectious Diseases. Ithaca, NY: IVIS. (1999).

137. Makloski CL. Canine Brucellosis Management. Vet Clin North Am Small Anim Pract. (2011) 41:1209-19. doi: 10.1016/j.cvsm.2011.08.001

138. Marzetti S, Carranza C, Roncallo M, Escobar GI, Lucero NE. Recent trends in human Brucella canis infection. Comp Immunol Microbiol Infect Dis. (2013) 36:55-61. doi: 10.1016/j.cimid.2012.09.002

139. Peres JN, Godoy AM, Barg L, Costa JO. Isolamento de Brucella canis de carrapatos (Rhipicephalus sanguineus). Arquivos da Escola de Veterinária da UFMG. (1981) 83:51-5.

140. Krueger WS, Lucero NE, Brower A, Heil GL, Gray GC. Evidence for unapparent Brucella canis infections among adults with occupational exposure to dogs. Zoonoses Public Health. (2014) 61:509-18. doi: $10.1111 /$ zph.12102

141. Chacón-Díaz C, Altamirano-Silva P, González-Espinoza G, Medina MC, Alfaro-Alarcón A, Bouza-Mora L, et al. Brucella canis is an intracellular pathogen that induces a lower proinflammatory response than smooth zoonotic counterparts. Infect Immun. (2015) 83:4861-70. doi: 10.1128/IAI.00995-15

142. Moreno E. Retrospective and prospective perspectives on zoonotic brucellosis. Front Microbiol. (2014) 5:213. doi: 10.3389/fmicb.2014.00213

143. Swenson R M, Carmichael LE, Cundy KR. Human infection with Brucella canis. Ann Intern Med. (1972) 76:435-8.

144. Monroe PW, Silberg SL, Morgan PM, Adess M. Seroepidemiological investigation of Brucella canis antibodies in different human population groups. J Clin Microbiol. (1975) 2:382-6.

145. Polt SS, Schaefer J. A microagglutination test for human Brucella canis antibodies. Am J Clin Pathol. (1982) 77:740-4.

146. Sayan M, Erdenlig S, Stack J, Kilic S, Guducuoglu H, Aksoy Y, et al. A serological diagnostic survey for Brucella canis infection in Turkish patients with Brucellosis-like symptoms. Jpn J Infect Dis. (2011) 64:516-9. 
147. Angel MO, Ristow P, Ko AI, Di-Lorenzo C. Serological trail of Brucella infection in an urban slum population in Brazil. J Infect Dev Ctries. (2012) 6:675-9. doi: $10.3855 /$ jidc. 2347

148. Young EJ. An overview of human brucellosis. Clin Infect Dis. (1995) 21:28390.

149. Tosi MF, Nelson TJ. Brucella canis infection in a 17-month-old child successfully treated with moxalactam. J Pediatr. (1982) 101:725-7.

150. Schoenemann J, Lutticken R, Scheibner E. Brucella canis infection in man. Deutsche Medizinische Wochenschrift. (1986) 111:20-2. doi 10.1055/s-20081068393

151. Wallach JC, Giambartolomei GH, Baldi PC, Fossati CA. Human Infection with M-strain of Brucella canis. Emerg Infect Dis. (2004) 10:146-8. doi: 10.3201/eid1001.020622

152. Lucero NE, Corazza R, Almuzara MN, Reynes E, Escobar GI, Boeri E, et al. Human Brucella canis outbreak linked to infection in dogs. Epidemiol Infect. (2010) 138:280-5. doi: 10.1017/S0950268809990525

153. Nomura A, Imaoka K, Imanishi H, Shimizu H, Nagura F, Maeda K, et al. Human Brucella canis infections diagnosed by blood culture. Emerg Infect Dis. (2010) 16:1183-5. doi: 10.3201/eid1607.090209

154. Godoy AM, Neves J, Peres JN, Barg GL. Human laboratory infection with Brucella canis. Arquivos Escola Vet Universidade Federal Minas Gerais. (1979) 31:141-5.

155. Traxler RM, Lehman MW, Bosserman EA, Guerra MA, Smith TL. A literature review of laboratory-acquired brucellosis. J Clin Microbiol. (2013) 51:3055-62. doi: 10.1128/JCM.00135-13

156. Pappas G, Akritidis N, Bosilkovski M, Tsianos E. Brucellosis. N Engl J Med. (2005) 352:2325-36. doi: 10.1056/NEJMra050570

157. Ying W, Nguyen MQ, Jahre JA. Brucella canis endocarditis: case report. Clin Infect Dis. (1999) 29:1593-4. doi: 10.1086/313545

158. McKee MA, Ballard JL. Mycotic aneurysms of the tibioperoneal arteries. Ann Vasc Surg. (1999) 13:188-90. doi: 10.1007/s100169900240

159. Piampiano P, McLeary M, Young LW, Janner D. Brucellosis: unusual presentations in two adolescent boys. Pediatr Radiol. (2000) 30:355-7. doi: $10.1007 / \mathrm{s} 002470050760$

160. Manias V, Nagel A, Mollerach A, Mendosa MA, Freyre H, Gómez A, et al. Brucella canis endocarditis: first documented case in Argentina. Rev Argent Microbiol. (2013) 45:50-3.

161. Gul HC, Erdem H, Bek S. Overview of neurobrucellosis: a pooled analysis of 187 cases. Int J Infect Dis. (2009) 13:e339-43. doi: 10.1016/j.ijid.2009.02.015

162. Babamahmoodi F, Babamahmoodi A. Brucellosis, presenting with Guillain-Barré syndrome. J Glob Infect Dis. (2011) 3:390-2. doi: 10.4103/0974-777X.91065

163. Lawaczeck E, Toporek J, Cwikla J, Mathison BA. Brucella canis in a HIV-infected patient. Zoonoses and Public Health. (2011) 58:150-2. doi: 10.1111/j.1863-2378.2010.01334.x

164. Lucero NE, Maldonado PI, Kaufman S, Escobar GI, Boeri E, Jacob NR. Brucella canis causing infection in an HIV-infected patient. Vector Borne Zoonotic Dis. (2010) 10:527-9. doi: 10.1089/vbz.2009.0034

165. Javeri H, Jamieson S, Sehgal R, Cadena J. Brucella canis peritonitis. Infection. (2014) 42:195-7. doi: 10.1007/s15010-013-0505-0

166. Scheftel J. Brucella canis: potential for zoonotic transmission. Compend Contin Educ Pract Vet. (2003) 25:846-53.

167. Figueiredo P, Ficht TA, Rice-Ficht A, Rossetti CA, Adams LG. Pathogenesis and immunobiology of brucellosis: review of Brucella-host interactions. Am J Pathol. (2015) 185:1505-17. doi: 10.1016/j.ajpath.2015.03.003

168. Byndloss MX, Tsolis RM. Brucella spp. virulence factors and immunity. Ann Rev Anim Biosci. (2016) 4:111-27. doi: 10.1146/annurev-animal-021815-111326

169. Paixão TA, Roux CM, den Hartigh AB, Sankaran-Walters S, Dandekar S, Santos RL, et al. Establishment of systemic Brucella melitensis infection through the digestive tract requires urease, the type IV secretion system, and lipopolysaccharide O-antigen. Infect Immun. (2009) 77:4197-208. doi: 10.1128/IAI.00417-09

170. López-Goñi I, Guzmán-Verri C, Manterola L, Sola-Landa A, Moriyón I, Moreno E. Regulation of Brucella virulence by the twocomponent system BvrR/BvrS. Vet Microbiol. (2002) 90:329-39. doi: 10.1016/S0378-1135(02)00218-3
171. Lapaque N, Moriyon I, Moreno E, Gorvel JP. Brucella lipopolysaccharide acts as a virulence factor. Curr Opin Microbiol. (2005) 8:60-6. doi: 10.1016/j.mib.2004.12.003

172. Allen CA, Adams LG, Ficht TA. Transposon-derived Brucella abortus rough mutants are attenuated and exhibit reduced intracellular survival. Infect Immun. (1998) 66:1008-16.

173. Jimenez-de-Bagues MP, Terraza A, Gross A, Dornand J. Different responses of macrophages to smooth and rough Brucella spp.: relationship to virulence. Infect Immun. (2004) 72:2429-33. doi: 10.1128/IAI.72.4.2429-2433.2004

174. Sá JC, Silva TM, Costa EA, Silva APC, Tsolis RM, Paixão TA, et al. The virBencoded type IV secretion system is critical for establishment of infection and persistence of Brucella ovis infection in mice. Vet Microbiol. (2012) 159:130-40. doi: 10.1016/j.vetmic.2012.03.029

175. Edmonds MD, Cloeckaert A, Booth NJ, Fulton WT, Hagius SD, Walker JV, et al. Attenuation of a Brucella abortus mutant lacking a major $25 \mathrm{kDa}$ outer membrane protein in cattle. Am J Vet Res. (2001) 62:1461-6.

176. Martín-Martín AI, Caro-Hernández P, Orduña A, Vizcaíno N, FernándezLago L. Importance of the Omp25/Omp31 family in the internalization and intracellular replication of virulent $B$. ovis in murine macrophages and $\mathrm{HeLa}$ cells. Microbes Infect. (2008) 10:706-10. doi: 10.1016/j.micinf.2008.02.013

177. O'Callaghan D, Cazevieille C, Allardet-Servent A, Boschiroli ML, Bourg G, Foulongne V, et al. A homologue of the Agrobacterium tumefaciens VirB and Bordetella pertussis Ptl type IV secretion systems is essential for intracellular survival of Brucella suis. Mol Microbiol. (1999) 33:1210-20. doi: 10.1046/j.1365-2958.1999.01569.x

178. Hong PC, Tsolis RM, Ficht TA. Identification of genes required for chronic persistence of Brucella abortus in mice. Infect Immun. (2000) 68:4102-7. doi: 10.1128/IAI.68.7.4102-4107.2000

179. Celli J, de Chastellier C, Franchini DM, Pizarro-Cerda J, Moreno E, Gorvel JP. Brucella evades macrophage killing via VirB-dependent sustained interactions with the endoplasmic reticulum. J Exp Med. (2003) 198:545-56. doi: 10.1084/jem.20030088

180. Blankenship RM, Sandford JP. Brucella canis: a case of undulant fever. Am J Med. (1975) 59:424-6.

181. Olsen SC, Palmer MV. Advancement of knowledge of Brucella over the past 50 years. Vet Pathol. (2014) 51:1076-89. doi: 10.1177/0300985814540545

182. Moore JA, Kakuk TJ. Male dogs naturally infected with Brucella canis. J Am Vet Med Assoc. (1969) 155:1352-8.

183. Ledbetter EC, Landry MP, Stokol T, Kern TJ, Messick JB. Brucella canis endophthalmitis in 3 dogs: clinical features, diagnosis, and treatment. Vet Ophthalmol. (2009) 12:183-91. doi: 10.1111/j.1463-5224.2009.00690.x

184. Anderson GI, Binnington AG. Discospondylitis and orchitis associated with high Brucella titre in a dog. Can Vet J. (1983) 24:249-52.

185. Kerwin SC, Lewis DD, Hribernik TN, Partington B, Hosgood G, Eilts BE. Diskospondylitis associated with Brucella canis infection in dogs: 14 cases (1980-1991). J Am Vet Med Assoc. (1992) 201:1253-7.

186. Carmichael LE. Abortion in 200 Beagles (News report). J Am Vet Med Assoc. (1966) 149:1126.

187. Moore JA, Gupta BN. Epizootiology, diagnosis, and control of Brucella canis. J Am Vet Med Assoc. (1970) 156:1737-40.

188. George LW, Duncan JR, Carmichael LE. Semen examination in dogs with canine brucellosis. Am J Vet Res. (1979) 40:1589-95.

189. George LW, Carmichael LE. Antisperm responses in male dogs with chronic Brucella canis infections. Am J Vet Res. (1984) 45:274-81.

190. Smeak DD, Olmstead ML, Hohn RB. Brucella canis osteomyelitis in two dogs with total hip replacements. J Am Vet Med Assoc. (1987) 191:986-90.

191. Henderson RA, Hoerlein BF, Kramer TT, Meyer ME. Discospondylitis in three dogs infected with Brucella canis. J Am Vet Med Assoc. (1974) 165:4515.

192. Kornegay JN, Barber DL. Diskospondylitis in dogs. J Am Vet Med Assoc. (1980) 177:337-41.

193. Thomas WB. Diskospondylitis and other vertebral infections. Vet Clin North Am Small Anim Pract. (2000) 30:169-82.

194. Yagupsky P, Morata P, Colmenero JD. Laboratory diagnosis of human brucellosis. Clin Microbiol Rev. (2020) 33:e00073-19.

195. Alton GG, Jones LM, Pietz DE. Laboratory Techniques in Brucellosis. Geneva: WHO (1975). 
196. Poester FP, Nielsen K, Samartino LE. Diagnosis of brucellosis. Open Vet Sci J. (2010) 4:46-60.

197. Mol JPS, França SA, Paixão TA, Santos RL. Laboratorial diagnosis of animal brucellosis. R Bras Ci Vet. (2012) 19:117-26. doi: 10.4322/rbcv.2014.106

198. Lista F, Reubsaet FA, De Santis R, Parchen RR, Jong AL, Kieboom J, et al. Reliable identification at the species level of Brucella isolates with MALDITOF-MS. BMC Microbiol. (2011) 11:267. doi: 10.1186/1471-2180-11-267

199. Sam IC, Karunakaran R, Kamarulzaman A, Ponnampalavanar S, Syed-Omar $\mathrm{SF}, \mathrm{Ng} \mathrm{KP}$, et al. A large exposure to Brucella melitensis in a diagnostic laboratory. J Hosp Infect. (2012) 80:321-5. doi: 10.1016/j.jhin.2011.12.004

200. Teixeira P, Valle S. Biossegurança: Uma Abordagem Multidisciplinar. Rio de Janeiro: Fiocruz (1996).

201. Carmichael LE. Brucelosis canina causada por B. canis: enfermedad clínica; problemas en inmunodiagnostico. Rev Med Vet. (1998) 80:102-6.

202. Greene CE, Carmichael LE. Canine brucellosis. In: Greene CE, editor. Infectious Diseases of the Dog and Cat. Philadelphia: WB Saunders Company (2012). p. 398-411.

203. Carmichael LE, Greene CE. Canine brucellosis. In: Greene CE, editor. Infectious Diseases of the Dog and the Cat. Philadelphia: WB Saunders (1998). p. $248-257$.

204. Johnson CA, Walker RD. Clinical signs and diagnosis of Brucella canis infection. Compend Contin Educ Vet. (1992) 114:763-72.

205. Bricker BJ. PCR as a diagnostic tool for brucellosis. Vet Microbiol. (2002) 90:435-46. doi: 10.1016/S0378-1135(02)00228-6

206. Keid LB, Soares RM, Vasconcellos SA, Chiebao DP, Megid J, Salgado VR, et al. A polymerase chain reaction for the detection of Brucella canis in semen of naturally infected dogs. Theriogenology. (2007) 67:1203-10. doi: 10.1016/j.theriogenology.2007.01.003

207. Keid LB, Soares RM, Vasconcellos SA, Chiebao DP, Salgado VR, Megid J, et al. A polymerase chain reaction for detection of Brucella canis in vaginal swabs of naturally infected bitches. Theriogenology. (2007) 68:1260-70. doi: 10.1016/j.theriogenology.2007.08.021

208. Keid LB, Soares RM. Vieira, NR. Megid J, Salgado VR, Vasconcellos $\mathrm{SA}$, et al. Diagnosis of canine brucellosis: comparison between serological and microbiological tests and a PCR based on primers to 16S-23S rDNA interspacer. Vet Res Commun. (2007) 31:951-65. doi: 10.1007/s11259-006-0109-6

209. Navarro E, Casao MA, Solera J. Diagnosis of human brucellosis using PCR. Expert Rev Mol Diagn. (2004) 4:115-23. doi: 10.1586/14737159.4.1.115

210. Keid LB, Soares RM, Vasconcellos SA, Salgado VR, Megid J, Richtzenhain LJ. Comparison of PCR assay in whole blood and serum specimens for canine brucellosis diagnosis. Vet Rec. (2010) 167:96-9. doi: 10.1136/vr. c3811

211. Leal-Klevezas DS, Martinez-Vazquez IO, Lopez-Merino A, Martinez-Soriano JP. Single-step PCR for detection of Brucella spp. from blood and milk of infected animals. J Clin Microbiol. (1995) 33:3087-90.

212. Morata P, Queipo-Ortuno MI, Colmenero JD. Strategy for optimizing DNA amplification in a peripheral blood PCR assay used for diagnosis of human brucellosis. J Clin Microbiol. (1998) 36: 2443-6.

213. Queipo-Ortuño MI, Garcia-Ordonez MA, Colmenero JD, Morata P. Hydrogen peroxide improves the efficiency of a peripheral blood PCR assay for diagnosis of human brucellosis. Biotechniques. (1999) 27:248-50.

214. Baily GG, Krahn JB, Drasar BS, Stoker NG. Detection of Brucella melitensis and Brucella abortus by DNA amplification. J Trop Med Hyg. (1992) 95:2715.

215. Herman L, Ridder H. Identification of Brucella spp. by using the polymerase chain reaction. Appl Environ Microbiol. (1992) 58:2099-101.

216. Romero C, Gamazo C, Pardo M, Lopez-Goni I. Specific detection of Brucella DNA by PCR. J Clin Microbiol. (1995) 33:615-7.

217. Scholz HC, Pfeffer M, Witte A, Neubauer H, Al Dahouk S, Wernery U, Tomaso H. Specific detection and differentiation of Ochrobactrum anthropi, Ochrobactrum intermedium and Brucella spp. by a multi-primer PCR that targets the recA gene. J Med Microbiol. (2008) 57:64-71. doi: 10.1099/jmm.0.47507-0

218. López-Goñi I, García-Yoldi D, Marín CM, de Miguel MJ, Muñoz PM, Blasco JM, et al. Evaluation of a multiplex PCR assay (Bruce ladder) for molecular typing of all Brucella species, including the vaccine strains. J Clin Microbiol. (2008) 46:3484-7. doi: 10.1128/JCM.00837-08
219. López-Goñi I, García-Yoldi D, Marín CM, de Miguel MJ, Barquero-Calvo E, Guzmán-Verri C, et al. New Bruce-ladder multiplex PCR assay for the biovar typing of Brucella suis and the discrimination of Brucella suis and Brucella canis. Vet Microbiol. (2011) 54:152-5. doi: 10.1016/j.vetmic.2011.06.035

220. Kang SI, Her M, Kim JW, Kim JY, Ko KY, Ha YM, et al. Advanced multiplex PCR assay for differentiation of Brucella species. Appl Environ Microbiol. (2011) 77:6726-8. doi: 10.1128/AEM.00581-11

221. Bricker BJ, Ewalt DR, Halling SM. Brucella HOOF-Prints: strain typing by multi-locus analysis of variable number tandem repeats (VNTRs). BMC Microbiol. (2003) 3:15. doi: 10.1186/1471-2180-3-15

222. Bricker BJ, Ewalt DR. Evaluation of the HOOF-print assay for typing Brucella abortus strains isolated from cattle in the United States: results with four performance criteria. BMC Microbiol. (2005) 5:37. doi: 10.1186/1471-2180-5-37

223. Le Flèche P, Jacques I, Grayon M, Al Dahouk S, Bouchon P, Denoeud F, et al. Evaluation and selection of tandem repeat loci for a Brucella MLVA typing assay. BMC Microbiol. (2006) 6:9. doi: 10.1186/1471-2180-6-9

224. Al Dahouk S, Le Fleche P, Nockler K, Jacques I, Grayon M, Scholz HC, et al. Evaluation of Brucella MLVA typing for human brucellosis. J Microbiol Methods. (2007) 69:137-45. doi: 10.1016/j.mimet.2006.12.015

225. Maquart M, Le Fleche P, Foster G, Tryland M, Ramisse F, Djonne B, et al. MLVA-16 typing of 295 marine mammal Brucella isolates from different animal and geographic origins identifies 7 major groups within Brucella ceti and Brucella pinnpedialis. BMC Microbiol. (2009) 9:145. doi: 10.1186/1471-2180-9-145

226. Queipo-Ortuño MI, Colmenero JD, Reguera JM, García-Ordoñez MA, Pachón ME, Gonzalez M, et al. Rapid diagnosis of human brucellosis by SYBR Green I-based real-time PCR assay and melting curve analysis in serum samples. Clin Microbiol Infect. (2005) 11:713-8. doi: 10.1111/j.1469-0691.2005.01202.x

227. Kattar MM, Zalloua PA, Araj GF, Samahakfoury J, Shbaklo H, Kanj SS, et al. Development and evaluation of real-time polymerase chain reaction assays on whole blood and paraffin-embedded tissues for rapid diagnosis of human brucellosis. Diagn Microbiol Infect Dis. (2007) 59:23-32. doi: 10.1016/j.diagmicrobio.2007.04.002

228. Gopaul KK, Koylass MS, Smith CJ, Whatmore AM. Rapid identification of Brucella isolates to the species level by real time PCR based single nucleotide polymorphism (SNP) analysis. BMC Microbiol. (2008) 8:86. doi: 10.1186/1471-2180-8-86

229. Hinic V, Brodard I, Thomann A. Novel identification and differentiation of Brucella melitensis, B. abortus, B. suis, B. ovis, B. canis and B. neotomae suitable for both conventional and real time PCR systems. J Microbiol Methods. (2008) 75:375-8. doi: 10.1016/j.mimet.2008.07.002

230. Queipo-Ortuño MI, Colmenero JD, Bravo M, García-Ordoñez MA, Morata P. Usefulness of a quantitative real-time PCR assay using serum samples to discriminate between inactive, serologically positive and active human brucellosis. Clin Microbiol Infect. (2008) 14:1128-34. doi: 10.1111/j.1469-0691.2008.02095.x

231. Bounaadja L, Albert D, Chénais B, Hénault S, Zygmunt MS, Poliak S, et al. Real-time PCR for identification of Brucella spp.: a comparative study of IS711, bcsp31 and per target genes. Vet Microbiol. (2009) 137:156-64. doi: 10.1016/j.vetmic.2008.12.023

232. Winchell JM, Wolff BJ, Tiller R, Bowen MD, Hoffmaster AR. Rapid identification and discrimination of Brucella isolates by use of real-time PCR and high-resolution melt analysis. J Clin Microbiol. (2010) 48:697-702. doi: 10.1128/JCM.02021-09

233. Keid LB, Soares RM, Vasconcellos SA, Megid J, Salgado VR, Richtzenhain LJ. Comparison of agar-gel immunodiffusion test, rapid slide agglutination test, microbiological culture and PCR for the diagnosis of canine brucellosis. Res Vet Sci. (2009) 86:22-6. doi: 10.1016/j.rvsc.2008.05.012

234. George LW, Carmichael LE. A plate agglutination test for the rapid diagnosis of canine brucellosis. Am J Vet Res. (1974) 35:905-9.

235. Badakhsh F, Carmichael L, Douglass J. Improved rapid slide agglutination test for presumptive diagnosis of canine brucellosis. J Clin Microbiol. (1982) 15:286-9.

236. Myers DM, Jones LM, Varela Diaz VM. Studies of antigens for complement fixation and diffusion tests in the diagnosis of infections caused by Brucella ovis and other Brucella. Appl Microbiol. (1972) 23:894-902. 
237. Carmichael LE, Joubert JC. A rapid slide agglutination test for the serodiagnosis of Brucella canis infection that employs a variant (M-) organism as antigen. Cornell Vet J. (1987) 77:3-12.

238. Mateu-de-Antonio EM, Martín M, Soler M. Used of indirect enzyme-linked immunosorbent assay with hot saline solution extracts of a variant (M-) strain of Brucella canis for diagnosis of brucellosis in dogs. Am J Vet Res. (1993) 54:1043-6.

239. Nielsen K, Smith P, Yu WL, Halbert G. Salmonella enterica serotype urbana interference with brucellosis serology. J Immunoassay Immunochem. (2007) 28:289-96. doi: 10.1080/15321810701454904

240. Damp SC, Crumrine MH, Lewis Jr GE. Microtiter Plate Agglutination test for Brucella canis antibodies. Appl Microbiol. (1973) 25:489-90.

241. Lucero NE, Escobar GI, Ayala SM, Lopez G. Sensitivity and specificity of an indirect enzyme-linked immunoassay for the diagnosis of Brucella canis infection in dogs. J Med Microbiol. (2002) 51:656-60. doi: 10.1099/0022-1317-51-8-656

242. Baldi PC, Wanke MM, Loza ME, Fossati CA. Brucella abortus cytoplasmic proteins used as antigens in an ELISA potentially useful for the diagnosis of canine brucellosis. Vet Microbiol. (1994) 41:127-34.

243. Baldi PC, Wanke MM, Loza ME, Monachesi N, Fossati CA. Diagnosis of canine brucellosis by detection of serum antibodies against an $18 \mathrm{kDa}$ cytoplasmatic protein of Brucella spp. Vet Microbiol. (1997) 57:273-81.

244. de Oliveira MZ, Vale V, Keid L, Freire SM, Meyer R, Portela RW, et al. Validation of an ELISA method for the serological diagnosis of canine brucellosis due to Brucella canis. Res Vet Sci. (2011) 90:425-31. doi: 10.1016/j.rvsc.2010.07.004

245. Serikawa T, Muraguchi T. Significance of urine in transmission of canine brucellosis. Jpn J Vet Sci. (1979) 41:607.

246. Wanke MM, Delpino MV, Baldi PC. Comparative performance of tests using cytosolic or outer membrane antigens of Brucella for the serodiagnosis of canine brucellosis. Vet Microbiol. (2002) 88:367-75.

247. Wanke M, Cairó F, Rossano M, Laiño M, Baldi PC, Monachesi NE, et al. Preliminary study of an immunochromatography test for serological diagnosis of canine brucellosis. Reprod Domest Anim. (2012) 47:370-2. doi: $10.1111 /$ rda. 12108

248. Worthington RW, Stevenson BJ, Lisle GW. Serology and semen culture for the diagnosis of Brucella ovis infection in chronically infected rams. $\mathrm{NZ} \mathrm{Vet}$ J. (1985) 33:84-6. doi: 10.1080/00480169.1985.35175

249. Mathias LA, Alberto LH, Roxo E, Perecin D, Girio RJS. Avaliação de uma microtécnica de fixação de complemento no diagnóstico sorológico da brucelose bovina e comparação entre os antígenos particulados e lipopolissacáride. Ars Vet. (1991) 7:38-48.

250. Hilbink F, Wright M, Ross G. Use of the double immuno gel diffusion test and the enzyme linked immunosorbent assay to distinguish false from true reactors in the complement fixation test for Brucella ovis. N Z Vet J. (1993) 41:111-5. doi: 10.1080/00480169.1993.35747

251. Estein SM. Aspectos inmunológicos em el diagnostico y control de la epididimitis contagiosa del carnero por Brucella ovis. Arch Med Vet. (1999) 31:5-17. doi: 10.4067/S0301-732X1999000100001

252. Azevedo SS, Vasconcellos AS, Keid LB, Grasso LMPS, Pinheiro SR, Mascolli $\mathrm{R}$, et al. Comparação de três testes sorológicos aplicados ao diagnóstico da infecção de caninos por Brucella canis. Braz J Vet Res Anim Sci. (2004) 41:106-12. doi: 10.1590/S1413-95962004000200005

253. Kim JW, Lee YJ, Han MY, Bae DH, Jung SC, Oh JS, et al. Evaluation of immunochromatographic assay for serodiagnosis of Brucella canis. J Vet Med Sci. (2007) 69:1103-7. doi: 10.1292/jvms.69.1103

254. Keid LB, Diniz JA, Oliveira TM, Ferreira HL, Soares RM. Evaluation of an immunochromatographic test to the diagnosis of canine brucellosis caused by Brucella canis. Reprod Domest Anim. (2015) 50:939-44. doi: $10.1111 /$ rda.12612

255. Lucero NE, Jacob NR, Ayala SM, Escobar GI, Tuccillo P, Jacques I. Unusual clinical presentation of brucellosis caused by Brucella canis. J Med Microbiol. (2005) 54:505-8. doi: 10.1099/jmm.0.45928-0

256. Thyagarajan B, Deshpande SS. Cotrimoxazole and neonatal kernicterus: a review. Drug Chem Toxicol. (2014) 37:121-9. doi: $10.3109 / 01480545.2013 .834349$
257. Ulu-Kilic A, Karakas A, Erdem H, Turker T, Inal AS, Ak O, et al. Update on treatment options for spinal brucellosis. Clin Microbiol Infect. (2014) 20:O75-82. doi: 10.1111/1469-0691.12351

258. Rousseau P. Brucella canis infection in a woman with fever of unknown origin. Postgrad Med. (1985) 78:249.

259. Munford RS, Weaver RE, Patton C, Feeley JC, Feldman RA. Human disease caused by Brucella canis: A clinical and epidemiologic study of two cases. J Am Med Assoc. (1975) 231:1267-9.

260. Al-Tawfiq JA. Therapeutic options for human brucellosis. Expert Rev AntiInfect Ther. (2008) 6:109-20. doi: 10.1586/14787210.6.1.109

261. Cosford KL. Brucella canis: An update on research and clinical management. Can Vet J. (2018) 59:74-81.

262. Zoha SJ, Walsh R. Effect of a two-stage antibiotic treatment regimen on dogs naturally infected with Brucella canis. J Am Vet Med Assoc. (1982) 180:14745.

263. Wanke MM, Delpino MV, Baldi PC. Use of enrofloxacin in the treatment of canine brucellosis in a dog kennel (clinical trial). Theriogenology. (2006) 66:1573-8. doi: 10.1016/j.theriogenology.2006.01.034

264. Hall WH, Manion RE. In vitro susceptibility of Brucella to various antibiotics. Appl Microbiol. (1970) 20:600-4.

265. Mateu-de-Antonio EM, Martín M. In vitro efficacy of several antimicrobial combinations against Brucella canis and Brucella melitensis strains isolated from dogs. Vet Microbiol. (1995) 45:1-10.

266. Fredrickson LE, Barton CE. A serologic survey for canine brucellosis in a metropolitan area. J Am Vet Med Assoc. (1974) 165:987-9.

267. Rhoades HE, Mesfin GM. Brucella canis infection in a kennel. Vet Med Small Anim Clin. (1980) 75:595-9.

268. Currier RW, Raithel WF, Martin RJ, Potter ME. Canine brucellosis. J Am Vet Med Assoc. (1982) 180:132-3.

269. Center for Food Security and Public Health. Canine Brucellosis: Brucella canis Contagious Abortion, Undulant Fever. Ames, IA: Center for Food Security and Public Health, Iowa State University (2012).

270. Megid J, Ribeiro MG, Moraes CCG, Nardi Júnior G, Paes AC, Prestes NC, et al. Brucelose canina - relato de caso. Arq Inst Biol. (2002) 69:103-6. doi: 10.1590/S0103-84781996000200024

271. Carvalho TF, Haddad JPA, Paixão TA, Santos RL. Meta-analysis and advancement of brucellosis vaccinology. PLoS ONE. (2016) 11:e0166582. doi: 10.1371/journal.pone.0166582

272. Palomares-Resendis G, Arellano B, Hernandez R, Tenorio V, Salas E, Suarez F, et al. Immunogenic response of Brucella canis virB10 and virB11 mutants in a murine model. Front Cell Infect Microbiol. (2012) 2:1-5. doi: 10.3389/fcimb.2012.00035

273. Qian J, Bu Z, Lang X, Yan G, Yang Y, Wang X, et al. A safe and moleculartagged Brucella canis ghosts confer protection against virulent challenge in mice. Vet Microbiol. (2017) 204:121-8. doi: 10.1016/j.vetmic.2017.04.027

274. Clausse M, Díaz AG, Ghersi G, Zylberman V, Cassataro J, Giambartolomei $\mathrm{GH}$, et al. The vaccine candidate BLSOmp31 protects mice against Brucella canis infection. Vaccine. (2013) 31:6129-35. doi: 10.1016/j.vaccine.2013.07.041

275. Clausse M, Díaz AG, Ibañez AE, Cassataro J, Giambartolomei GH, Estein SM. Evaluation of the efficacy of outer membrane protein 31 vaccine formulations for protection against Brucella canis in BALB/c mice. Clin Vaccine Immunol. (2014) 21:1689-94. doi: 10.1128/CVI.00527-14

276. Pollak CN, Wanke MM, Estein SM, Delpino MV, Monachesi NE, Comercio EA, et al. Immunization with Brucella VirB proteins reduces organ colonization in mice through a Th1-type immune response and elicits a similar immune response in dogs. Clin Vaccine Immunol. (2015) 22:274-81. doi: 10.1128/CVI.00653-14

277. Truong QL, Cho Y, Kim K, Park BK, Hahn TW. Booster vaccination with safe, modified, live-attenuated mutants of Brucella abortus strain RB51 vaccine confers protective immunity against virulent strains of $B$. abortus and Brucella canis in BALB/c mice. Microbiology. (2015) 161:2137-48. doi: $10.1099 /$ mic. 0.000170

278. Stranahan LW, Chaki SP, Garcia-Gonzalez DG, Khalaf OH, Arenas-Gamboa AM. Evaluation of the efficacy of the Brucella canis RM6/66 $\Delta$ vjbR vaccine candidate for protection against B. canis infection in mice. mSphere. (2020) 5:00172-20. doi: 10.1128/mSphere.00172-20 
279. Eckstein C, Mol JP, Costa FB, Nunes PP, Lima PA, Melo MM, et al. Brucella ovis mutant in $\mathrm{ABC}$ transporter protects against Brucella canis infection in mice and it is safe for dogs. PLoS ONE. (2020) 15:e0231893. doi: 10.1371/journal.pone. 0231893

280. Silva APC, Macêdo AA, Costa LF, Turchetti AP, Bull V, Pessoa MS, et al. Brucella ovis lacking a species-specific putative ATPbinding cassette transporter is attenuated but immunogenic in rams. Vet Microbiol. (2013) 167:546-53. doi: 10.1016/j.vetmic.2013. 09.003

281. Frost A. Feeding of raw Brucella suis-infected meat to dogs in the UK. Vet Rec. (2017) 181:484. doi: 10.1136/vr.j 4972

282. Wareth G, El-Diasty M, Melzer F, Murugaiyan J, Abdulmawjood A, Sprague LD, et al. Trueperella pyogenes and Brucella abortus coinfection in a dog and a cat on a dairy farm in Egypt with recurrent cases of mastitis and abortion. Vet Med Int. (2018) 2018:2056436. doi: 10.1155/2018/2056436

Conflict of Interest: The authors declare that the research was conducted in the absence of any commercial or financial relationships that could be construed as a potential conflict of interest.

Copyright $(2021$ Santos, Souza, Mol, Eckstein and Paíxão. This is an open-access article distributed under the terms of the Creative Commons Attribution License (CC

$B Y)$. The use, distribution or reproduction in other forums is permitted, provided the original author(s) and the copyright owner(s) are credited and that the original publication in this journal is cited, in accordance with accepted academic practice. No use, distribution or reproduction is permitted which does not comply with these terms. 